\title{
Contractual Features of CEO Performance-Vested Equity Compensation
}

\author{
Zhan Gao \\ Lancaster University \\ z.gao@lancaster.ac.uk \\ Yuhchang Hwang \\ China Europe International Business School \\ hwangy@ceibs.edu \\ Wan-Ting $\mathrm{Wu}^{*}$ \\ University of Massachusetts, Boston \\ wan-ting.wu@umb.edu
}

Draft: July 2017

\footnotetext{
We thank Martin Conyon, David Erkens, John H. Evans III, Francesca Franco, Christo Karuna, John O’Hanlon, Bart Lambrecht, Michal Matějka, Ken Peasnell, Banerjee Shantanu, Steve Young, and workshop participants at the China Europe International Business School and Lancaster University, and participants at the 2012 American Accounting Association Management Accounting Section Mid-year Conference, the 2012 European Accounting Association Annual Congress, the 2012 American Accounting Association Annual Meeting, and the 2017 Journal of Contemporary Accounting and Economics Annual Symposium for their helpful comments.

* The corresponding author.
} 


\title{
CONTRACTUAL FEATURES OF CEO PERFORMANCE-VESTED EQUITY COMPENSATION
}

\begin{abstract}
We investigate the key contractual features of CEO performance-vested (p-v) equity compensation. We hypothesize that contractual features such as relative performance evaluation (RPE), the performance period length, and the number of performance metrics can be configured to improve the informativeness of performance metrics. Consistent with the hypotheses, we find that firms using market metrics are more likely to adopt RPE and long performance periods than firms using accounting metrics. The effects of performance metrics on RPE and performance periods remain prominent after we allow these features to be jointly determined. Moreover, we find that RPE is positively associated with longer performance periods, suggesting that the two features complement each other in improving the informativeness of performance metrics in p-v equity compensation. Our findings not only reveal the intricate relations between the contractual features, but also provide empirical support for the voting guidelines by proxy advisory services and have implications for the evolving practice of executive compensation.
\end{abstract}

Keywords: CEO compensation, contract design, performance metrics, relative performance evaluation, performance period, corporate governance

JEL Classification: G34, G38, J33 


\section{INTRODUCTION}

Against the backdrop of the ongoing pursuit of pay-for-performance by investors and regulators, performance-vested (p-v) equity awards have emerged as a key component of CEOs' long-term compensation in US firms. In 2013, 78.2\% of non-financial firms in the S\&P 500 granted p-v equity awards to CEOs, a marked increase from 58.1\% in 2006 (Table 7, Panel A). The growing popularity of p-v equity compensation suggests the necessity of having a thorough understanding of its contractual design.

Different from traditional time-vested (t-v) equity compensation, a p-v equity award requires recipients to achieve pre-determined performance targets before vesting. Since 2006, firms have been required to disclose detailed performance provisions of p-v equity awards in their proxy statements. For example, Intel discloses its p-v equity award as follows:

"OSUs granted to the listed officers in 2012 have a three-year performance period from the grant date... The number of shares of Intel common stock to be received at vesting will range from $50 \%$ to $200 \%$ of the target amount, based on the TSR [total shareholder return] of Intel common stock measured against the TSR of the technology peer group over a three-year period." 1

In this example, the vesting of Intel's p-v equity grant is based on a single performance metric-TSR, which is measured over a three-year performance period and benchmarked against Intel's peers, a feature called relative performance evaluation (RPE). ${ }^{2}$ The complexity of p-v equity compensation contracts not only raises an important issue concerning the optimality of its design, but also poses practical challenges for shareholders seeking to evaluate such contracts and for firms trying to design them. In this study, we investigate the

\footnotetext{
${ }^{1}$ From Intel's 2012 proxy statement (available at https://www.sec.gov/Archives/edgar/data/50863/000119312513138873/d424609ddef14a.htm). OSU stands for outperformance stock unit.

${ }^{2}$ Relative performance evaluation entails a comparison of firm performance against peers when evaluating an executive's performance.
} 
determination and interdependence of the key contractual features of CEO p-v equity compensation. Specifically, we examine (i) whether the salient contractual features in CEO pv equity compensation, such as the use of RPE, the performance period length, and the number of metrics, depend on the type of performance metrics, (ii) firms' choice of performance metrics, and the joint determination of performance metrics and the other three contractual features, and (iii) whether RPE, the performance period length, and the number of metrics complement or substitute for each other in enhancing the informativeness of performance metrics.

A thorough investigation of these questions is warranted for several reasons. First, p-v equity compensation has attracted increasing scrutiny from investors. Prominent proxy advisory services such as the Institutional Shareholder Services (ISS) and Glass Lewis have issued voting guidelines that call for close examination of the contractual features of $\mathrm{p}-\mathrm{v}$ equity awards. Certain features, such as RPE, long performance periods, and multiple metrics, have been deemed to be elements of a well-structured incentive plan (Glass Lewis 2015, p. 29; more details in Appendix A; ISS 2015, pp. 38-39). However, despite the growing importance of p-v equity compensation, our knowledge of its contractual design remains limited. ${ }^{3}$ Also, evidence is lacking with respect to whether proxy advisory services’ recommendations have an empirical basis or whether such designs are indeed beneficial.

Second, p-v equity compensation provides a unique and rich setting to investigate the contractual features of executive compensation. Many features of $\mathrm{p}-\mathrm{v}$ equity compensation are not present in annual bonuses and t-v equity compensation and have not been thoroughly investigated in the literature. ${ }^{4}$ For example, RPE is a common feature in p-v equity compensation, whereas it is rarely used in annual bonuses. The performance period of $\mathrm{p}-\mathrm{v}$

\footnotetext{
${ }^{3}$ We are only aware of a few prior studies on the design of p-v equity compensation; see, e.g., Bettis et al. (2010); Bettis et al. (2016); De Angelis and Grinstein (2015).

${ }^{4}$ Most prior research focuses on annual bonuses and t-v equity compensation (e.g., Lambert and Larcker 1987; Ittner et al. 1997; Core et al. 2003; Matějka et al. 2009).
} 
equity compensation varies considerably in length, while it is nearly always one year in annual bonuses.

More importantly, the coexistence of all these explicit performance features in p-v equity compensation allows us to examine their intricate relations. Existing literature has primarily examined individual features of equity compensation in isolation. ${ }^{5}$ Because the terms of $\mathrm{p}-\mathrm{v}$ equity compensation contracts are likely negotiated in an integrated manner, treating individual contractual features in isolation limits our understanding of these complex compensation contracts. In this paper, we depart from prior studies by explicitly addressing the joint determination of contractual features of p-v equity compensation.

Our main objective is to examine the relations between performance metrics and three salient contractual features of p-v equity compensation: RPE, the performance period length, and the number of metrics. Linking vesting to the achievement of performance targets, $\mathrm{p}-\mathrm{v}$ equity compensation tends to incentivize recipients more effectively than traditional $t-\mathrm{v}$ equity compensation. However, because the payout is subject to achievement of performance targets, p-v equity compensation also entails higher volatility than traditional equity compensation. We argue that firms can mitigate the extra volatility in p-v equity compensation through contractual features such as RPE, the performance period length, and the number of metrics, all of which play a role in influencing the informativeness of performance metrics. Specifically, RPE helps filter out performance-irrelevant common shocks that affect market metrics more than accounting metrics. Moreover, extending performance periods can smooth out short-term volatility in market metrics (Campbell and Viceira 2002). Considering that market metrics incorporate more forward-looking and richer information (Collins et al. 1987), firms using market metrics may need fewer additional

\footnotetext{
${ }^{5}$ For example, Carter et al. (2009) study the use of RPE in p-v equity compensation, Cadman et al. (2013) examine the vesting terms of option grants, and De Angelis and Grinstein (2015) analyze performance metrics.
} 
performance metrics. Therefore, we hypothesize that, in p-v equity compensation, firms using market metrics are more likely to adopt RPE, set longer performance periods, and use fewer performance metrics than firms using accounting metrics.

We test these predictions in a sample of S\&P 500 industrial firms that granted p-v equity compensation to CEOs between 2006 and 2013. The results show that firms using market metrics are more likely to adopt RPE and set longer performance periods than firms using accounting metrics. These findings are consistent with our hypotheses that RPE and the performance period are tuned to enhance the informativeness of performance metrics and to insulate recipients from excessive risk. However, we do not find that firms with market metrics use fewer metrics.

While the preceding analyses treat firms’ choice of performance metrics as exogenous, we proceed to examine explicitly the use of market metrics in CEO p-v equity compensation. The results show that firms with less noisy market metrics, more complex operations, and better past stock performance are more likely to use market metrics than accounting metrics. When re-examining the determination of the three contractual features (RPE, performance period length, and number of metrics) jointly with that of performance metrics, we obtain robust findings confirming that RPE and long performance periods are more likely to coexist with market metrics.

In the third analysis, we examine the interdependence of RPE, the performance period length, and the number of metrics. The purpose of this analysis is to investigate whether these contractual features complement or substitute for each other in CEO p-v equity compensation. The results show that RPE complements longer performance periods, consistent with the prediction that firms configure a multitude of contractual features to filter out compensation risk and enhance the informativeness of performance metrics. 
In the supplementary analyses, we confirm that the relations between the contractual features of p-v equity compensation are robust after considering the firm's choice of granting p-v equity awards, the use of compensation consultants, and the impacts of other forms of compensation such as stock options and annual bonuses. We also find that firms designing their CEO p-v equity compensation according to our hypotheses (i.e., using market metrics with RPE and long performance periods) subsequently outperform the rest of the firms.

This paper makes several contributions to the literature as well as the evolving compensation practice. First, we contribute to the underdeveloped research on the complexity of compensation contracts (e.g., Kole 1997). Unlike prior studies that examine individual features of equity compensation contracts in isolation (e.g., Carter et al. 2009; Matějka et al. 2009; De Angelis and Grinstein 2015), we approach these features collectively. This systematic approach reveals the intricate relations between contractual features and better captures the complex nature of compensation design. Second, we add evidence for the design of p-v equity compensation, the fastest-growing form of executive performance pay among US firms. The unique features of p-v equity compensation contracts, such as the frequent use of market metrics and RPE and the wide variation in performance periods, allow us to test one of the principles in compensation design-incentive-risk trade-off. Third, the findings in our study have implications for the evolving practice of executive equity compensation. The documented relations between key p-v contractual features and the performance consequence of compensation design provide an empirical basis for the voting guidelines by proxy advisory services, which endorse certain contractual features of p-v equity awards as favorable (Glass Lewis 2015; ISS 2015).

The rest of the paper is organized as follows. Section II reviews the relevant literature and develops the hypotheses. The sample and data are described in Section III. We discuss the 
empirical results in Section IV. Section V presents the supplementary analyses and Section VI concludes.

\section{LITERATURE REVIEW AND HYPOTHESES}

\subsection{P-v equity compensation and related literature}

In the past decade, US firms have significantly increased grants of p-v equity awards which link the vesting to the achievement of performance targets. Among S\&P 500 industrial firms, the percentage granting p-v equity awards to CEOs increases from $58.1 \%$ in 2006 to 78.2\% in 2013 (Table 7, Panel A). Over the same period, p-v equity compensation as a percentage of total compensation value rises from 18\% to 29\% (Panel A, Figure 1). Evans et al. (2017) report a similar trend in a broader sample of S\&P 1500 firms.

Early evidence shows that firms grant p-v equity compensation to incentivize executives and to sort managerial talents, rather than to extract rent or placate stakeholders (Gerakos et al. 2007; Bettis et al. 2010). Based on a larger and more recent sample, Bettis et al. (2016) provide additional insights concerning the valuation and incentive properties of p-v equity awards. However, Abernethy et al. (2015) show that powerful CEOs influence the adoption and design of p-v stock options for their own benefits.

While p-v equity compensation is a relatively recent phenomenon in the US, it has been popular in the UK, mostly in the form of p-v stock options, due to the influence of the corporate governance code issued by the Greenbury Committee in 1995. Several studies have investigated the use of p-v stock options by UK firms. For example, Câmara (2001) analytically demonstrates that p-v stock options with RPE do not provide stronger incentives to executives to improve shareholder wealth than traditional t-v stock options, but they do encourage executives to take on risky projects. Kuang and Qin (2009) find evidence that, compared to t-v stock options, $\mathrm{p}-\mathrm{v}$ stock options are associated with greater interest alignment between executives and shareholders. 


\subsection{Prior literature on compensation contract features}

Performance metrics, especially those used in annual bonuses, have been well studied in the literature (e.g., Lambert and Larcker 1987; Ittner et al. 1997; Core et al. 2003; Matějka et al. 2009; De Angelis and Grinstein 2015). These studies commonly find that, consistent with the informativeness principle (Holmstrom 1979), the choice of metrics—for example, accounting versus market (Lambert and Larcker 1987; Core et al. 2003) or financial versus non-financial (Ittner et al. 1997; Matějka et al. 2009) —is related to the metric’s relative informativeness. Strategy and past performance also affect the choice of performance metrics (Ittner et al. 1997; De Angelis and Grinstein 2015).

RPE is another contractual feature that has attracted academic interest. The early literature only tests the “implicit” use of RPE (e.g., Janakiraman et al. 1992; Murphy 1999) because few US firms disclosed the use of RPE in executive compensation prior to 2006. One exception is Carter et al. (2009), who employ UK data to examine the use and characteristics of RPE in CEO p-v equity compensation. They find some evidence that the adoption of RPE is associated with economic factors such as common shocks, industry concentration, and a CEO’s ability to hedge. Since the Securities and Exchange Commission’s (SEC’s) regulation on compensation disclosure in 2006, the data on RPE use in US executives' performancebased pay have become directly available, and several studies have documented the economic determinants of RPE adoption (Gong et al. 2011; Bettis et al. 2014).

Few studies have examined other contractual features such as the performance period. Among the exceptions, Evans et al. (2017) theorize and empirically test whether the performance period is designed to facilitate the sorting of managerial talents. Cadman et al. (2013) examine the determination of vesting terms for t-v stock options and report that the vesting terms are longer in firms with higher growth, less powerful CEOs, and more institutional holdings. 


\subsection{Hypothesis development}

The literature has long viewed performance metrics as a central feature of executive compensation contracts and demonstrated that the choice of performance metrics plays a pivotal role in determining the efficacy of p-v equity compensation (e.g., Holmstrom 1979; Bushman and Smith 2001). The voting guidelines of proxy advisory services also suggest the choice of performance metrics as a key consideration from shareholders' standpoint (Glass Lewis 2015). Therefore, we argue that most firms prioritize the choice of performance metrics when designing p-v equity compensation. Once the performance metrics are chosen, firms next consider other contractual features such as RPE, the performance period length, and whether to use additional performance metrics to improve the informativeness of performance metrics. Moreover, in proxy statements, firms usually explain and justify the choice of performance metrics more carefully than the rest of the contractual arrangements such as RPE and performance periods. ${ }^{6}$ To the extent that the presentation in the proxy statement indicates the importance and decisional sequence from firms'standpoint, this observation provides additional support for the presumed decisional sequence in designing pv equity compensation. ${ }^{7}$

We hypothesize that the choice of performance metrics is associated with three salient contractual features of p-v equity compensation: RPE, the performance period length, and the number of metrics. Unlike t-v equity compensation, p-v equity compensation subjects the vesting to the achievement of performance criteria and thus injects additional volatility into

\footnotetext{
${ }^{6}$ For example, Coca-Cola states in its 2012 proxy statement: “...growth in economic profit has been chosen as the performance measure for the annual awards because it is an important measure of the Company's longterm strength and is historically correlated with stock price over time. ... A three-year performance period was selected to mirror our long-term business planning cycle.” (https://www.sec.gov/Archives/edgar/data/21344/000130817913000057/lcocacola2013_def14a.htm\#_N57)

${ }^{7}$ We acknowledge that some firms may not follow exactly the decision sequence as described above. For example, they may decide the use of RPE or the length of performance period first or decide these contractual features simultaneously. Regardless of the decision process, the contents of our hypotheses remain intact. That is, we still predict a positive relation between the use of market metrics and the use of RPE/long performance periods and a negative relation between the use of market metrics and the number of metrics used in $\mathrm{p}-\mathrm{v}$ equity compensation.
} 
compensation. Mindful of the cost, both firms and CEOs strive to negotiate terms that alleviate excess volatility induced by p-v equity compensation.

While numerous types of performance metrics are used for executive compensation in practice, they fall into two broad categories: market metrics and accounting metrics. ${ }^{8}$ Market metrics are distinct from accounting metrics and are generally considered to be more timely and informative (e.g., Beaver et al. 1987; Collins et al. 1987; Freeman 1987). In the following hypotheses, we focus on the ways in which the three contractual features filter noise out of market metrics and reduce the volatility of compensation.

Use of RPE. Agency theory suggests that RPE should be used when a performance metric contains significant shocks that are common among peers (e.g., Baiman and Demski 1980; Holmstrom 1982). Compared to accounting metrics, market metrics move more closely with broad stock markets and are more subject to common shocks. By benchmarking against its peers, a firm can effectively filter out common shocks and enhance the informativeness of market metrics. Moreover, implementing RPE for market metrics is less expensive than it is for accounting metrics because stock prices or returns of peers are consistently defined and easily accessible. In contrast, accounting metrics are less comparable across firms because a large variety of accounting metrics is used in practice, and the wide use of accounting measures that do not conform to generally accepted accounting principles makes it even more challenging to compare performance across companies.

$\mathrm{H1}$ : In p-v equity compensation, the use of RPE is more strongly associated with market metrics than with accounting metrics.

Performance period length. The type of performance metrics also has implications for the performance period. Short-term market movements disproportionately affect stock

\footnotetext{
${ }^{8}$ In the final sample of this paper (1,442 firm years), $60.8 \%$ uses only accounting metrics in their CEO p-V equity compensation, $21.1 \%$ uses only market metrics, $16.9 \%$ uses both accounting and market metrics, and $1.2 \%$ uses other types of performance metrics. See Section 3.2 for more details.
} 
returns/prices and render these metrics too volatile over short horizons (e.g., Campbell and Viceira 2002). By extending performance periods, a firm can smooth out short-term, performance-irrelevant fluctuations in market metrics, which allows market metrics to capture managerial efforts more effectively. In contrast, accounting metrics are not as volatile as market metrics (Chen et al. 2012), so firms using accounting metrics may not benefit as much from long performance periods as firms using market metrics. This argument leads to our second hypothesis.

H2: $\quad$ In p-v equity compensation, longer performance periods are more strongly associated with market metrics than with accounting metrics.

Number of metrics. Firms must balance cost and benefit when deciding how many performance metrics to use in p-v equity compensation. On the one hand, employing multiple metrics enhances the overall precision of the combined signal and may improve the efficacy of compensation contracts. On the other hand, measuring executives’ performance against multiple metrics can be costly because extra metrics introduce additional volatility into compensation and complicate the performance evaluation process. Given that market metrics embed richer information than accounting metrics (e.g., Collins et al. 1987), it is plausible to suggest that firms using a market metric for $\mathrm{p}-\mathrm{v}$ equity compensation do not need additional metrics to improve informativeness of performance metrics, especially if the cost of using additional metrics outweighs their informational benefit. Therefore, we predict that firms using market metrics in p-v equity compensation are less likely to use extra performance metrics. In contrast, firms that use accounting metrics in p-v equity compensation are more likely to use multiple metrics because a single accounting metric often does not suffice to capture executives’ complex and multi-faceted decisions. Hence, we hypothesize ${ }^{9}$ :

\footnotetext{
${ }^{9} \mathrm{H} 3$ is developed on the premise that firms trade informational benefit against measurement cost associated with the use of multiple metrics. This trade-off argument is only meaningful if the measurement cost is substantial. Due to the unobservable nature of the measurement cost, we view the relation between the choice
} 
H3: $\quad$ In $p-v$ equity compensation, firms using market metrics are less likely to use multiple metrics than firms using accounting metrics.

\section{III.SAMPle, DATA, AND DESCRIPTIVE STATISTICS}

\subsection{Sample and data}

Our sample is composed of S\&P 500 industrial firms (excluding financial services and utilities) that granted p-v equity compensation to CEOs from 2006 through $2013 .{ }^{10}$ This set of firms was chosen because they represent the broad economy well, and their compensation practices are likely to influence those employed by other firms. The sample period starts from 2006 because that is the first year when firms followed the SEC's new regulation on compensation disclosure and disclosed detailed features of executive compensation in proxy statements.

Contractual features of p-v equity compensation, such as the type and number of performance metrics and the performance period length, are obtained from the compensation consulting firm Equilar. Among the p-v equity awards granted to the sample firms’ CEOs, $61.5 \%$ is in the form of restricted stock units, followed by $35.3 \%$ in the form of restricted stock, while the remaining $3.2 \%$ is in the form of stock options and stock appreciation rights (SARs). In our sample, 83.1\% of firm years only grants one p-v equity award to CEOs, and the remaining $16.9 \%$ grants more than one p-v equity award. In the reported analyses, we only use the contractual features of the award with the largest fair value at the grant date. ${ }^{11}$ In addition, we collect the RPE data by hand from proxy statements.

Additional data are obtained from diverse sources: accounting data from COMPUSTAT, stock prices and returns from the Center for Research in Security Prices (CRSP), CEO

\footnotetext{
of performance metrics and the use of multiple metrics as essentially an empirical issue, and our aim here is more exploratory than explanatory.

${ }^{10}$ The earlier version of our paper uses p-v equity compensation of all named executives. The results remain qualitatively unchanged.

11 The inclusion of multiple p-v equity awards does not alter our key findings and inferences materially.
} 
compensation data from ExecuComp, and corporate governance data from RiskMetrics and Thomson Financial. The final sample contains 1,442 firm-years and 331 unique firms (see Table 1 for the detailed sample construction process). All variables in this paper are defined in Appendix B.

From 2006 to 2013, the relative importance of p-v equity awards in executives’ overall compensation packages has increased. Panel A of Figure 1 shows that p-v equity compensation as a percentage of total compensation value rose from $18 \%$ in 2006 to $29 \%$ in 2013. Panel B of Figure 1 indicates that, within long-term equity compensation, the percentage of p-v equity compensation also grew from 35\% in 2006 to $45 \%$ in 2013.

\subsection{Contractual features of p-v equity awards}

Panel A of Table 2 summarizes the frequencies of performance metrics used in p-v equity compensation, which fall into the following types: earnings (52.0\%), asset utilization (28.7\%), sales (23.2\%), cash (10.5\%), collectively referred to as accounting metrics; market metrics based on stock prices and returns (38.1\%); other financial metrics (6.4\%); and nonfinancial metrics (5.3\%). ${ }^{12}$ The data also reveal changes in practice over time. For example, firms increase the use of market metrics (from 30.3\% in 2006-2008 to $41.4 \%$ in $2009-2013$ ) but decrease their reliance on earnings or asset utilization metrics (from 55.2\% and $34.7 \%$ in 2006-2008 to $50.6 \%$ and $26.1 \%$ in $2009-2013)$.

Panel B of Table 2 reports the use of RPE in p-v equity compensation. A firm is considered to use RPE if any performance metric in its CEO p-v equity compensation is benchmarked against its peers or an index. In our sample, 40.5\% adopts RPE, while the

\footnotetext{
12 Earnings metrics include measures derived from earnings (or profits), such as net income, adjusted net income, operating income, and earnings growth. Asset utilization metrics include return on equity, return on assets, return on invested capital, and economic value added ${ }^{\circledR}$, among others. Sales (cash) metrics include those derived from sales/revenue (cash flows), both level and growth. Examples of non-financial metrics include customer satisfaction, safety, and innovation. Given the wide variety of performance metrics used in practice, we used our judgment in the categorization in some cases.
} 
remaining firms set targets without reference to peers’ performance. ${ }^{13}$ Panel B also reports the length of the period over which performance is measured to determine the actual payout of equity awards. Among the sample firms, 68.5\% measures performance over three years. The seemingly high proportion of one-year performance periods (20.2\%) is puzzling considering that nearly all firms claim to use p-v equity awards as a form of long-term incentive compensation.

Panel C shows that slightly more than half of the sample firms (51.9\%) use a single performance metric, 37.7\% uses two metrics, and the rest use more than two metrics. The tendency to use fewer metrics appears to contrast with Holmstrom’s (1979) well-known argument that firms should rely on multiple metrics as long as each metric provides independent information concerning CEOs’ efforts.

The contractual features of p-v equity compensation are stable over the sample period. The persistence of these features partly reflects the fact that firms do not continuously revise compensation contracts; they only do so at intervals or after significant corporate events (e.g., CEO turnover, merger and acquisition).

\section{EMPIRICAL RESULTS}

\subsection{Relations between performance metrics and the other three contractual features}

According to Hypotheses 1-3, in p-v equity compensation the type of performance metrics is related to RPE use, the performance period length, and the number of metrics because these three features are instrumental in enhancing the informativeness of performance metrics and reducing excessive volatility in compensation. We test these hypotheses individually using binary choice models.

\footnotetext{
13 The prevalence of RPE in our sample differs from that in Bettis et al. (2010). It is worth noting that numerous regulatory and economic changes have occurred since the end of the sample period that Bettis et al. (2010) used, which largely covers the 1990s.
} 
Use of RPE

To test H1, we model the firm's decision to use RPE as follows:

$$
\begin{aligned}
\text { RPE }_{t}=\alpha_{0} & +\alpha_{1} \text { Market }_{t}+\alpha_{2} \text { ComShk }_{t-1}+\alpha_{3} \text { IndConcen }_{t-1} \\
& +\alpha_{4} \text { CEOWlth }_{t-1}+\alpha_{5} \text { CEOAge } \text { CE }_{t-1}+\alpha_{6} \mid \text { Ret_RkAdj }_{t-1} \\
& +\alpha_{7} \text { AdjROA }_{t-1}+\text { Controls }+\varepsilon_{t} .
\end{aligned}
$$

The dependent variable RPE equals one if any performance metric in a firm's CEO p-v equity compensation is benchmarked against its peers or an index, and zero otherwise. The key independent variable Market equals one if a firm uses market metrics, and zero otherwise. ${ }^{14} \mathrm{H} 1$ predicts the coefficient of Market to be positive. The rest of the independent variables are based on extensive prior literature (e.g., Aggarwal and Samwick 1999; Garvey and Milbourn 2003; Gong et al. 2011). Holmstrom (1982) theorizes that firms facing more common shocks are more likely to adopt RPE to filter out common shocks (ComShk; predicted to be positive). Other studies identify settings in which RPE is less beneficial: when competition is high (industry competition, IndConcen; predicted to be negative), executives are able to self-hedge common shocks (CEO wealth, CEOWlth, and age, CEOAge; both predicted to be negative), or when suitable peers are not available (availability of peers, $\mid$ Ret_RkAdj|; predicted to be positive).

We are mindful that CEOs can take advantage of compensation negotiations to extract rent from shareholders. Rent extraction may become more prevalent when CEOs are more influential and/or firms have weak monitoring mechanisms or corporate governance. To address this issue, Model (1) follows prior literature (e.g., Cadman et al. 2013; Abernethy et al. 2015) and includes corporate governance characteristics, namely, institutional holdings $(I H)$, the independence of the board of directors (BrdIndp), the dual role of CEO as chairperson of the board (Dual), and a newly appointed CEO (CEONew). Following Gong et

\footnotetext{
${ }^{14}$ The use of market metrics does not preclude firms from using accounting metrics. In our sample, $16.9 \%$ of firms uses both market and accounting metrics. The results are robust if the sample is restricted to firms using either market-based or accounting-based performance metrics only (but not both types).
} 
al. (2011), we also control for firm performance (AdjROA3), firm size (Size), and growth potential (BM). Model (1) is estimated as a logit regression with year fixed effect and the standard errors of coefficient estimates are clustered by firm.

Panel A of Table 3 shows that among firms that use market metrics in p-v equity compensation, the rate of adopting RPE is $87.8 \%$, a stark contrast to the rate of $11.4 \%$ among firms that use only accounting metrics. ${ }^{15}$ This pattern is consistent with H1, which suggests that RPE is particularly compatible with market metrics.

Panel B of Table 2 shows the descriptive statistics of the key variables in this analysis and the correlations between the dependent variable $R P E$ and the independent variables. RPE is used in $40.5 \%$ of our sample firms, and market metrics are used in $38.1 \%$ of our sample firms. The average age of the CEO in our sample is 55.95 years. The $R P E$ has higher correlations with Market (0.755) than with other variables (e.g., 0.142 with ComShk; -0.079 with IndConcen).

Panel C of Table 3 reports the logit estimation of Model (1). Model (1.i) serves as the benchmark and includes the determinants of RPE documented in prior literature: common shocks (ComShk), competition (IndConcen), self-hedging ability (CEOWlth and CEOAge), and availability of peers (|Ret_RkAdj|), among other control variables. Consistent with prior empirical findings (e.g., Gong et al. 2011), ComShk carries a positive coefficient, suggesting that firms subject to more common shocks are more likely to adopt RPE. Similarly, IndConcen has the predicted negative sign, consistent with the notion that high competition hinders the use of RPE. The positive coefficient of CEOAge $(\mathrm{p}<0.05)$ suggests that RPE is more likely to apply to older CEOs, who are less able to diversify the risk of equity grants and thus may find RPE more attractive.

\footnotetext{
${ }^{15}$ Among firms not using market metrics, the vast majority (98.1\%) uses accounting metrics, while only $1.9 \%$ uses "other financial” or "non-financial” metrics.
} 
Model (1.ii) includes our main variable of interest, Market. The variable has a positive and highly significant coefficient (4.122 with a marginal effect $0.774, \mathrm{p}<0.01)$, which confirms H1 suggesting that firms using market metrics are more likely to adopt RPE than firms using accounting metrics. In economic terms, the propensity to adopt RPE is $77 \%$ higher in firms using market metrics than in firms using accounting metrics. More importantly, Market effectively renders ComShk, IndConcen, and CEOAge insignificant in Model (1.ii), which suggests that the use of market metrics is an essential factor that determines the use of RPE and its power dominates the other determinants. This economic significance of Market is further evident from the remarkable improvement in the model fit: The pseudo $R^{2}$ rises from $4.7 \%$ in (1.i) to $47.8 \%$ in (1.ii).

The additional controls of governance and CEO characteristics in Model (1.iii) do not diminish the significance of Market or the main inference of H1. Among the corporate governance variables, the positive coefficient of board independence (BrdIndp, 4.574 with a marginal effect 1.056, $\mathrm{p}<0.01$ ) is consistent with Gong et al. (2011), who suggest that firms with stronger internal governance favor RPE because RPE limits the pay-for-luck practice and also benefits risk-sharing. The positive and significant coefficient of Dual is inconsistent with the inference concerning broad independence. A potential interpretation is that entrenched CEOs can influence the selection of peers so that RPE works in their favor. Performance period length and number of metrics

$\mathrm{H} 2$ pertains to the relation between the type of performance metric and the performance period length. We test this using the following binary choice model:

$$
\begin{aligned}
\text { LongPeriod }_{t}=\beta_{0} & +\beta_{1} \text { Market }_{t}+\beta_{2} \text { AdjROA3 }_{t-1}+\beta_{3} \text { Ex Cash }_{t-1}+\beta_{4} \text { Volt }_{t-1} \\
& +\beta_{5} \text { Invst }_{t-1}+\beta_{6} \text { Segmt }_{t-1}+\text { Controls }+\xi_{t} .
\end{aligned}
$$

The dependent variable LongPeriod equals one if the performance period spans at least three years, and zero otherwise. Market is the main independent variable of interest, which $\mathrm{H} 2$ predicts to carry a positive coefficient. Among the rest of the independent variables in 
Model (2), we first include variables that capture the need for retention, a key factor that determines the length of the vesting period. These variables are included here because two thirds of our sample firms have an equal length of performance period and vesting period; the same factors that determine the vesting period may also affect the performance period. Based on Cadman et al. (2013), the need for retention is high when past performance (measured by AdjROA3) is good or when it is costly to replace the existing CEO (measured by a CEO's excessive cash compensation, ExCash).

The second group of independent variables in Model (2) measures a firm's decisionmaking environment. In uncertain business environments (measured by stock return volatility, Volt), short performance horizons expedite the performance evaluation and allow timely assessment of executives’ productivity, resulting in better sorting of managerial talent (Lazear 1995). Moreover, when a firm invests extensively and/or operates complex businesses (measured by Invst3 and Segmt, respectively), more time is needed to observe the consequences of the CEO’s decisions. Therefore, we predict that such firms are more likely to choose long performance periods. Model (2) also controls for corporate governance characteristics (IH, BrdIndp, Dual, and CEONew).

We use the following binary choice model to test H3 regarding the number of metrics:

$$
\begin{aligned}
\text { MultMetrics } t_{t}=\gamma_{0} & +\gamma_{1} \text { Market }_{t}+\gamma_{2} \text { Volt }_{t-1}+\gamma_{3} \text { Invst }_{t-1}+\gamma_{4} \text { Segmt }_{t-1} \\
& + \text { Controls }+\zeta_{t} .
\end{aligned}
$$

The dependent variable MultMetrics equals one if a firm uses more than one metric, and zero otherwise. Among the independent variables, market metrics, Market, is expected to carry a negative coefficient because $\mathrm{H} 3$ predicts that firms employing market metrics use fewer metrics than those using accounting metrics. Model (3) includes proxies for business environment uncertainty (Volt), investment intensity (Invst3), and business complexity (Segmt). When a firm operates in an uncertain business environment, invests heavily, or has 
complex operations, the informativeness of any single metric is likely limited and it may be more beneficial to use multiple metrics in compensation contracts. For example, evidence shows diminished information quality in complex business environments: Duru and Reeb (2002) find that analysts produce less accurate forecasts for complex businesses, and Bushman et al. (2004) show that investors are less able to learn about the activities of complex organizations. Both Models (2) and (3) control for firm characteristics (BM, Size) and corporate governance characteristics (IH, BrdIndp, Dual, and CEONew).

Panel A of Table 4 compares the performance period length and the number of metrics between firms using market metrics and those not using them. The left-hand side of Panel A shows that the vast majority of firms that rely on market metrics sets the performance period for at least three years (96.0\%), whereas the percentage drops to $62.6 \%$ among the rest of the firms. This pattern is consistent with the prediction in $\mathrm{H} 2$ that firms using market metrics are more likely to set longer performance periods. H3 predicts that firms using market metrics are less likely to use multiple performance metrics in $\mathrm{p}-\mathrm{v}$ equity compensation. The righthand side of Panel A weakly supports this prediction: $45.4 \%$ of the firms using market metrics chooses additional metrics for their p-v equity compensation, slightly lower than the $49.7 \%$ of firms that does not use market metrics.

In Panel B of Table 3, the use of market metrics is significantly and positively correlated with the use of long performance periods (Pearson correlation 0.376, $\mathrm{p}<0.01$ ), but its correlation with the use of multiple metrics is not significant. Business complexity (measured by Segmt) is positively correlated with long performance periods and multiple metrics (Pearson correlations 0.060 and 0.052, respectively).

Panel C of Table 4 empirically tests H2 in the multivariate logit model (2). As in Table 3, we compare Model (2.ii) with Model (2.i) to highlight the effect of performance metrics. Consistent with our prediction, the coefficient for Market is significant and positive (2.654 
with a marginal effect 0.328, $\mathrm{p}<0.01$ ). Economically, this finding suggests that, in CEO $\mathrm{p}-\mathrm{v}$ equity awards, firms using market metrics are 32.8\% more likely to set long performance periods than firms only using accounting metrics. The economic significance of Market is also demonstrated by the significant improvement in the model fit: The pseudo $\mathrm{R}^{2}$ of Model (2.ii), $16.6 \%$, is more than six times that of Model (2.i). The significant effect of Market is robust to the inclusion of the governance and CEO characteristics in Model (2.iii). However, the signs of $I H, B r d I n d p$ and Dual suggest conflicting inferences for corporate governance. One possible reason is that these proxies may not precisely capture the underlying constructs of board monitoring and/or CEO entrenchment.

Panel D of Table 4 presents our test of H3 using the multivariate logit model (3). The results show no association between the use of market metrics and the use of multiple metrics (Market is insignificant in both Models (3.ii) and (3.iii)). The inconsistency between these results and the prediction in $\mathrm{H} 3$ may be due to the measurement costs not being high enough to influence a firm's decision to use multiple metrics. Firms therefore prefer additional metrics as long as they contribute to new performance-relevant information. Another explanation may be that most firms follow the guidelines of Glass Lewis (2015), which suggest using multiple metrics for long-term incentive plans.

In summary, the empirical findings in Table 3 and Table 4 suggest that the choice of performance metrics is strongly associated with two important features of CEO p-v equity compensation-RPE and the performance period length. The documented relations are consistent with the notion that firms use RPE or a long performance period to improve the informativeness of market metrics and to reduce excessive volatility in compensation. However, we do not find a relation between metric type and the use of multiple metrics. 


\subsection{The choice of performance metrics and joint determination of performance metrics and the other contractual features}

The empirical testing of the hypotheses in the preceding section treats the choice of performance metrics in p-v equity compensation as exogenous. Given that all the contractual features in p-v equity compensation contracts are negotiated as a package, treating the choice of metrics as exogenous is less than satisfactory. Moreover, the importance of performance metrics warrants an investigation of how firms choose these metrics for p-v equity compensation. Therefore, in this section, we start by examining the use of market metrics in CEOs’ p-v equity compensation. Drawing on prior theoretical and empirical literature, we discuss several factors that affect firms' choice of market versus accounting performance metrics in p-v equity compensation: relative volatility of metrics, nature of business, and past performance.

Relative volatility of metrics. One key implication of the informativeness principle is that the weight of a performance metric in compensation contracts decreases with the metric's relative noisiness, which implies that firms should avoid metrics that are too noisy to provide information about CEOs’ actions (e.g., Holmstrom 1979; Bushman and Smith 2001).

Empirically, Lambert and Larcker (1987) find that in annual bonuses, firms give more weight to market metrics than to accounting metrics when the variance in accounting metrics is high relative to that in market metrics. Provided that the informativeness principle also applies to p-v equity compensation, we predict that firms are less prone to use market metrics if the relative volatility of market metrics increases.

Nature of business. The nature of a firm's business, such as the level of investment opportunities and business complexity, is also key to determining the choice of performance metrics. Prior research (e.g., Smith and Watts 1992; Baber et al. 1996) argues that it is critical for a manager facing substantial investment opportunities to make forward-looking and longterm decisions. These decisions, however, often have a negative impact on short-term 
accounting performance. Therefore, linking compensation with accounting metrics may create the wrong incentive for managers when many investment opportunities exist. Evidence also shows that organizational complexity creates considerable coordination and control challenges for managers (e.g., Mittal et al. 2004), suggesting that accounting information may not be sufficient to reveal the effort of executives in complex organizations. Therefore, rather than using accounting metrics, firms with greater investment opportunities or complex business operations are more likely to use market metrics because stock prices and returns are forward-looking and incorporate more timely and richer information than accounting metrics.

Past performance. Matějka et al. (2009) find that firms in financial distress are less likely to use non-financial metrics (as opposed to financial metrics) in their CEOs' annual bonuses, suggesting that distressed firms use financial metrics to incentivize CEOs to improve profitability and expedite turnaround. In the same vein, one may expect firms with poor stock (operating) performance to demand that their CEOs make efforts to improve stock (operating) performance. Such firms can do so by linking the vesting of equity awards to the achievement of market (accounting) performance targets.

Empirically, we use the following binary choice model to examine the use of market metrics in CEO p-v equity compensation:

$$
\begin{aligned}
\text { Market }_{t}=c_{0} & +c_{1} \text { RtVar }_{t-1}+c_{2} \text { Segmt }_{t-1}+c_{3} \text { Invst }_{t-1} \\
& +c_{4} \text { BHAR3 }_{t-1}+c_{5} \text { AdjROA3 }_{\mathrm{t}-1}+c_{6} \text { BM }_{t-1}+c_{7} \text { Size }_{t-1} \\
& +c_{8} \text { IH }_{t-1}+c_{9} \text { BrdIndp }_{t-1}+c_{10} \text { Dual }_{t-1}+c_{11} \text { CEONew }_{t-1}+\varepsilon_{t} .
\end{aligned}
$$

The dependent variable Market is defined as before. Among the independent variables, we follow Lambert and Larcker (1987) to measure the relative volatility between market and accounting metrics (RtVar) as the standard deviation of stock returns divided by the standard deviation of return on assets (ROA) over past twelve quarters. The informativeness principle predicts the coefficient of RtVar to be negative. Proxying for the nature of business, Segmt and Invst3 are predicted to have positive coefficients. BHAR3 (AdjROA3) measures a firm's 
stock (operating) performance and is predicted to have a negative (positive) sign. We control for the same firm and the corporate governance characteristics as in Models (1) through (3).

Panel A of Table 5 shows the estimation of Model (4) via logit regressions, where (4.i) and (4.ii) differ in the measures of past firm performance. The relative volatility of market metrics to accounting metrics (RtVar) has a negative coefficient as expected: When market metrics are noisier than accounting metrics, they are less likely to be used in p-v equity compensation. As predicted, both business complexity (Segmt) and investment intensity (Invst3) are positively and significantly associated with a firm's propensity to use market metrics, consistent with the notion that market metrics better capture performance-relevant information in complex decision-making environments.

The positive and significant coefficient on BHAR3 in Model (4.ii) is inconsistent with our earlier prediction regarding past performance. The result instead suggests that firms with good past stock performance tend to choose market metrics for CEO p-v equity compensation. One possible interpretation is that firms choose performance metrics that are important for their goals and strategies, and this importance is correlated to the performance level achieved in the past. An alternative explanation is that CEOs "cherry-pick" metrics in which firms previously performed well to increase the vesting of their equity awards. ${ }^{16}$

In the rest of the section, we re-test the hypotheses by treating the use of market metrics as a decision made jointly with those involving the other contractual features. This analysis alleviates the caveat of the findings in the preceding section where the choice of performance metrics is treated as exogenous. Panel B of Table 5 reports the joint estimation of each of the three contractual feature models—(1), (2), and (3) — with the market metric model (4), using seemingly unrelated probit regressions. The results are qualitative, similar to those in Section

\footnotetext{
${ }^{16}$ This "rent extraction" explanation relies on the premise that executives have the means to sustain past good performance into the future, which may be problematic given the well-known mean-reverting phenomenon in firm performance.
} 
4.1. The robustness of our results suggests that after allowing for the joint determination of performance metrics and each of the other contractual features, the use of market metrics still has a dominant influence on firms' use of RPE and long performance periods in CEO p-v equity compensation.

\subsection{Interdependence among contractual features}

The analyses in the preceding sections assume that the three contractual features- RPE, performance period length, and number of metrics — are independent in the design of p-v equity compensation. In this section, we extend the analyses by allowing these three features to be interdependent. Our goal is to examine whether firms adopt these features simultaneously and whether there is any trade-off in their use.

The literature argues that RPE is more effective when common shocks in performance exceed idiosyncratic shocks (e.g., Gong et al. 2011; Janakiraman et al. 1992). Prolonging the performance period decreases short-term idiosyncratic noise in performance metrics and increases the relative weight of common shocks, which makes RPE more beneficial. Therefore, we argue that RPE is more compatible with long performance periods than with short performance periods.

The relation between the number of metrics and the other two features is less clear. On the one hand, a firm may use multiple metrics along with RPE and long performance periods in p-v equity compensation because all of these features can potentially improve the informativeness of performance metrics. On the other hand, it can be costly to adopt multiple metrics because of the measurement cost and indirect cost such as conflicting incentives resulting from multiple metrics. Moreover, over a long period, the informational advantage of market metrics relative to accounting metrics is likely to decline because in the long run both 
types of metrics tend to capture a firm's underlying fundamentals more effectively. Thus, the need for multiple metrics could decrease over long periods.

Panel A of Table 6 shows the associations among RPE, the performance period length, and the number of metrics. As predicted, the use of RPE is associated with long performance periods: $94.9 \%$ of RPE firms sets their performance periods for at least three years, whereas the percentage drops to only $62.0 \%$ for non-RPE firms. The relation between RPE and the number of metrics is not as clear: 52.1\% of RPE firms uses multiple metrics, similar to nonRPE firms at 51.9\%.

To examine the interdependence between the three contractual features in a multivariate setting, we use the following system of equations:

$$
\begin{aligned}
\text { RPE }_{t}=\alpha_{0} & +\alpha_{1} \text { Market }_{t}+\alpha_{2} \text { ComShk }_{t-1}+\alpha_{3} \text { IndConcen }_{t-1} \\
& +\alpha_{4} \text { CEOWlth }_{t-1}+\alpha_{5} \text { CEOAge }_{t-1}+\alpha_{6} \mid \text { Ret_RkAdj }_{t-1} \\
& +\alpha_{7} \text { AdjROA }_{t-1}+\text { Controls } \varepsilon_{t}, \\
\text { LongPeriod }_{t}=\beta_{0} & +\beta_{1} \text { RPE }_{t}+\beta_{2} \text { Market }_{t}+\beta_{3} \text { AdjROA }_{t-1}+\beta_{4} \text { ExCash }_{t-1} \\
& +\beta_{5} \text { Volt }_{t-1}+\beta_{6} \text { Invst }_{t-1}+\beta_{7} \text { Segmt }_{t-1}+\text { Controls }+\zeta_{t}, \\
\text { MultMetrics }_{t}=\gamma_{0} & +\gamma_{1} \text { RPE }_{t}+\gamma_{2} \text { LongPeriod }_{t}+\gamma_{3} \text { Market }_{t}+\gamma_{4} \text { Volt }_{t-1} \\
& +\gamma_{5} \text { Invst }_{t-1}+\gamma_{6} \text { Segmt }_{t-1}+\text { Controls }_{t}+\xi_{t}, \\
\text { Market }_{t}=C_{0} & +c_{1} \text { RtVar }_{t-1}+c_{2} \text { Segmt }_{t-1}+c_{3} \text { Invst }_{t-1}+c_{4} \text { BHAR }_{t-1} \\
& + \text { Controls }_{t} v_{t} .
\end{aligned}
$$

Each of Equations (5a) through (5d) concerns one of the contractual features examined in the preceding sections: the use of RPE (RPE), performance period length (LongPeriod), number of metrics (MultMetrics), and the use of market metrics (Market). This system of equations has a recursive structure: That is, Equation (5a) only includes Market as an independent variable (includes neither LongPeriod nor MultMetrics), Equation (5b) includes $R P E$ and Market, and Equation (5c) includes RPE, LongPeriod, and Market. This recursive structure is necessary for the estimation purpose because a system of fully endogenized latent 
variables would be unidentifiable (see Greene 2011). ${ }^{17}$ The remaining (exogenous) independent variables are the same as those in Models (1) through (4).

Panel B of Table 6 reports the results of the joint estimation of (5a) through (5d) by seemingly unrelated probit regressions. The findings are summarized as follows. First, in Equation (5b), the coefficient of LongPeriod is positive and significant $\left(\hat{\beta}_{1}=0.827, \mathrm{p}<0.01\right)$, suggesting that long performance periods are often co-adopted with RPE. Second, in Equation (5c), neither RPE nor LongPeriod is significant, a finding that is not entirely unexpected in light of the frequency counts in Panel A. Third, consistent with the results in the previous sections, Market is still positively and significantly associated with $R P E$ and LongPeriod (in Equations (5a) and (5b), respectively), suggesting that our primary findings are robust even after we account for the potential interdependence among these features. Last, in Equation (5d), all determinants of the use of market metrics remain significant and consistent with the results in Section 4.2. This finding suggests that the choice of performance metrics is an independent process and not affected by choices of other contractual features; this lends additional support to our methodology of treating the use of market metrics as exogenous in Section 4.1.

Overall, our analyses reveal the interdependence among the key contractual features in CEO p-v equity compensation. The finding that firms adopting RPE are more likely to set long performance periods suggests that these two features are complementary in their roles to improve the informativeness of performance metrics. However, we do not find a definite relation between the number of metrics and other features.

\footnotetext{
${ }^{17}$ A recursive system implies that certain endogenous variables are considered as exogenous to the other endogenous variables (e.g., in Equation (5a) through (5c), $R P E$ is considered as exogenous to LongPeriod and MultMetrics). We also examine an alternative specification in which LongPeriod is treated as exogenous to $R P E$ and MultMetrics. The results are similar.
} 


\section{SUPPLEMENTARY ANALYSES}

\subsection{Grant of p-v equity awards and its influence on the design of p-v equity compensation}

As the goal of this study is to investigate the key contractual features of p-v equity compensation, we restrict our sample to those firms that grant this form of compensation to CEOs. An issue of sample selection may arise if a firm's decision to adopt p-v equity compensation affects the design of such contracts. To address this concern, we first examine firms’ decision to adopt p-v equity compensation using Model (6):

$$
\begin{aligned}
P V_{t}=a_{0} & +a_{1} \text { BHAR3 }_{t-1}+a_{2} \text { Volt }_{t-1}+a_{3} \text { Invst }_{t-1}+a_{4} \text { Segmt }_{t-1} \\
& + \text { Controls }+\varepsilon_{t}
\end{aligned}
$$

where $P V$ equals one if a firm grants p-v equity awards, and zero otherwise. Following Bettis et al. (2010), we include prior performance (BHAR3), uncertainty in business environment (Volt), investment intensity (Invst3), and business complexity (Segmt), as well as firm and corporate governance characteristics as before.

Panel A of Table 7 shows the frequency of firms with and without p-v equity awards. In our sample, $64.3 \%$ of the firms grants p-v equity awards, much higher than the adoption rates in earlier data (e.g., Bettis et al. 2010). Panel A also shows the increasing popularity of p-v equity compensation in our sample period: The adoption rate rises from 58.1\% in 2006 to 78.2\% in 2013. Panel B shows the estimation result of Model (6) by logit regression. Firms with heavy investment (Inves3) are less likely to grant p-v equity awards, whereas firms with more independent boards (BrdIndp) are more likely to do so. Panel C re-estimates the contractual features of Models (1) through (4) using the Heckman selection procedure. All the key findings are qualitatively similar to those in Table 3 , Table 4 , and Table 5 , so the concern regarding sample selection bias is relieved. 


\subsection{Design of p-v equity contracts and future performance}

Throughout the analyses in Section 4, we rely on the informativeness principle to hypothesize and predict the relations between contractual features. A natural question arises concerning the validity of such a premise. If these compensation contracts are indeed efficiently designed, they should incentivize CEOs and foretell better future performance compared to cases in which compensation is inefficiently designed. Analyzing the relation between contract design and future performance not only demonstrates the economic consequence of compensation design, but also helps to validate our underlying assumption of efficient contracting.

To test whether the design of p-v equity compensation is related to firms' future performance, we compare future operating performance of two contrasting groups, distinguished by their contract designs. The first group of firms designs p-v equity compensation according to Hypotheses 1 and 2, which are derived from the informativeness principle and supported by the data. This group uses market metrics in conjunction with RPE and long performance periods. The second group consists of the remaining firms, whose p-v equity compensation does not follow this configuration. Following Bettis et al. (2010), we measure operating performance by industry-adjusted return on assets.

As Table 8 shows, the “consistent design” group achieves significantly better operating performance than the contrasting group, up to the subsequent four years. The results support the premise of our empirical analyses that such a configuration of contractual features reflects the efficacy of compensation contracts and also suggest that p-v equity compensation is not merely a means for CEOs to extract rent or placate shareholders.

\subsection{Influence of compensation consultants on contractual features}

Prior studies have shown that compensation consultants affect CEO pay levels (e.g., Cadman et al. 2010; Murphy and Sandino 2010; Armstrong et al. 2012). Cadman et al. (2010) 
indicate that compensation consultants have different specialties. For example, F. W. Cook specializes in compensation design for CEOs and directors, whereas other top consulting firms provide a wider range of services. As a supplementary analysis, we examine whether compensation consultants influence the design of p-v equity compensation. We collect by hand the compensation consultant data for our sample between 2006 and 2008. Over this period, the top four consulting firms are F. W. Cook (hired by $21.3 \%$ of the sample), Towers Perrin (21.0\%), Hewitt (15.4\%), and Mercer (15.4\%), whose market shares are well ahead of the fifth firm, Watson Wyatt (6.2\%). We re-estimate the contractual features of Models (1) through (4) using dummy variables for the four most popular consulting firms. In the untabulated results, we find that controlling for consulting firms does not alter our key conclusions about the influence of performance metrics on the other contractual features. The results also show some style effects of consulting firms on the design of p-v equity compensation: For example, firms hiring Towers Perrin and Hewitt tend to set long performance periods, those hiring F. W. Cook use fewer performance metrics, and those hiring Hewitt are more likely to choose market metrics.

\subsection{Influence of other forms of compensation on the design of p-v equity awards}

Because CEOs receive a mix of compensation, one may ask how other forms of compensation influence the design of p-v equity awards. As a robustness check, we examine the effect of t-v equity awards and annual bonuses, two key components of executive compensation. First, we examine whether the pay-performance-sensitivity (PPS) of t-v equity awards affects the key features of p-v equity awards. PPS is chosen because of its central role in the efficacy of $\mathrm{t}-\mathrm{v}$ equity awards (in contrast to $\mathrm{p}-\mathrm{v}$ equity compensation, the design of $\mathrm{t}-\mathrm{v}$ equity compensation is much simpler). Empirically, we follow Core and Guay (2002) and measure PPS by the delta and vega of t-v equity awards (in the form of stock options, 
restricted stock, and restricted stock units). The untabulated results show that our main conclusions are robust to controlling delta and vega of t-v equity awards.

Second, we examine whether the performance metrics in annual bonuses affect the contractual features of p-v equity awards. Because annual bonuses are a major form of incentive pay that focuses on short-term performance, it is plausible to assume that annual bonuses are designed in conjunction with p-v equity awards. The design of annual bonuses is simpler and the use of performance metrics is the most prominent feature. Empirically, we include in Models (1) through (4) a set of dummy variables, each indicating one of the main types of metrics used in annual bonuses: earnings, asset utilization, sales, cash, market, other financial, and non-financial. The untabulated results show that our main results are robust to the control for performance metrics in annual bonuses.

\subsection{Different modeling of the performance period and the number of metrics}

In the main analyses, we dichotomize the performance period length and the number of metrics. ${ }^{18}$ The decision is justified because the original data are discrete and not suitable for ordinary least squares (OLS) regressions. Specialized count data models, such as the Poisson regression and negative binomial regression, are subject to restrictive assumptions. As a robustness check, we use two alternative methods, OLS regressions and zero-truncated Poisson regressions, to estimate Model (2) for the performance period length and Model (3) for the number of metrics. In both cases, the results are qualitatively similar to those reported in Table 4.

\section{CONCLUSION}

We investigate the determination of and interdependence among the contractual features of CEO p-v equity compensation, with an aim to shed light on the complex design of

\footnotetext{
${ }^{18}$ Recall that LongPeriod equals one when the performance period is at least three years and zero otherwise; MultMetrics equals one when the number of metrics is more than one and zero otherwise.
} 
compensation contracts. This investigation is warranted because the existing research on compensation design is largely confined to annual bonuses and t-v stock options and does not fully address the intricate relations among features of $\mathrm{p}-\mathrm{v}$ equity compensation.

Although p-v equity compensation provides stronger incentives to executives than traditional t-v equity compensation, it also exposes executives to higher risk. Following the core insight that an efficient compensation contract trades incentive against risk, we hypothesize that the three salient features of $p-v$ equity compensation- $-R P E$, performance period length, and number of metrics — are configured to filter excessive risk and to increase the informativeness of performance metrics.

We empirically test these predictions in a sample of S\&P 500 industrial firms granting pv equity awards to CEOs between 2006 and 2013. As predicted, we find that firms using market metrics are more likely to adopt RPE and to set long performance periods. However, we find no relation between the use of market metrics and the number of metrics.

We next examine firms' decision to use market metrics in p-v equity compensation. The results show that firms with less volatile market metrics, better past stock returns, and complex businesses are more likely to use market metrics. Importantly, our main findings concerning the effect of performance metrics on the other features are robust after allowing for the joint determination of contractual features.

We further explore the interdependence among RPE, the performance period length, and the number of metrics and document that RPE complements long performance periods in enhancing the informativeness of performance metrics. Moreover, the results demonstrate the consequences of contractual design: Firms that use market metrics in conjunction with RPE and long performance periods for $\mathrm{p}-\mathrm{v}$ equity compensation exhibit better future operating performance than the rest of the firms. Our results are robust after we control for the grant 
decision of p-v equity awards, the impact of compensation consultants, the features of $t-v$ equity awards and annual bonuses, and alternative estimation techniques.

Overall, our findings are consistent with the notion that key contractual features of $\mathrm{p}-\mathrm{v}$ equity compensation are configured to enhance the informativeness of performance metrics and to isolate executives from unwanted risk. Our results reveal the complex relations among these features and are relevant to the evolving practice of executive compensation. Against the backdrop of intense public scrutiny, this study can contribute to the heated debate concerning flaws and possible reforms of executive compensation. Future research may investigate the design of $\mathrm{p}-\mathrm{v}$ equity compensation in relation to executive turnover and its design in firms with poor performance. 


\section{REFERENCES}

Aggarwal, R., \& Samwick, A. (1999). Executive compensation, strategic competition, and relative performance evaluation: Theory and evidence. The Journal of Finance, LIV (6), 1999-2043.

Abernethy, M., Kuang, Y., \& Qin, B. (2015). The influence of CEO power on compensation contract design. The Accounting Review 90 (4): 1265-1306.

Armstrong, C. Ittner, C., \& Larker, D. (2012). Corporate governance, compensation consultants, and CEO pay levels. Review of Accounting Studies 17 (2): 322-351.

Baiman, S., \& Demski, J. (1980). Economically optimal performance evaluation and control systems. Journal of Accounting Research, 18 (1), 184-220.

Baber, W., Janakiraman, S., \& Kang, S. (1996). Investment opportunities and the structure of executive compensation. Journal of Accounting and Economics 21, 297-318.

Beaver, W., Lambert, R., \& Ryan, S. (1987). The information content of security prices: A second look. Journal of Accounting and Economics, 9 (2), 139-157.

Bettis, C., Bizjak, J., Coles, J., \& Kalpathy, S. (2010). Stock and option grants with performance-based vesting provisions. The Review of Financial Studies, 23 (10), 38493888.

Bettis, C., Bizjak, J., Coles, J., \& Kalpathy, S. (2016). Performance-vesting provisions in executive compensation. Working paper, http://papers.ssrn.com/sol3/papers.cfm?abstract_id=2289566.

Bettis, C., Bizjak, J., Coles, J., \& B. Young. (2014). The presence, value, and incentive properties of relative performance evaluation in executive compensation contracts. Working paper, Arizona State University, http://papers.ssrn.com/sol3/papers.cfm?abstract_id=2392861.

Bushman, R., \& A. Smith. (2001). Financial accounting information and corporate governance. Journal of Accounting and Economics 32 (1-3): 237-333.

Bushman, R., Q. Chen, \& E. Engel. (2004). Financial accounting information, organizational complexity and corporate governance systems. Journal of Accounting and Economics 37: 167-201.

Cadman, B., M. Carter, \& Hillegeist, S. (2010). The incentives of compensation consultants and CEO pay. Journal of Accounting and Economics 49 (3): 263-280.

Cadman, B., Rusticus, T., \& Sunder, J. (2013). Stock option grant vesting terms: Economic and financial reporting determinants. Review of Accounting Studies 18 (4): 1159-1190.

Câmara, A. (2001). The Pricing of Relative Performance Based Incentives for Executive Compensation. Journal of Business Finance \& Accounting 28 (9-10): 1115-1139.

Campbell, J. \& Viceira, L. (2002). Strategic Asset Allocation: Portfolio Choice for LongTerm Investors. Oxford University Press.

Carter, M., Ittner, C., \& Zechman, S. (2009). Explicit relative performance evaluation in performance-vested equity grants. Review of Accounting Studies, 14 (2-3): 269-306. 
Chen, C., Huang, A., \& Jha, R. (2012). Idiosyncratic return volatility and the information quality underlying managerial discretion. Journal of Financial \& Quantitative Analysis 47 (4): 873-899.

Collins, D., Kothari, S., \& Rayburn, J. (1987). Firm size and the information content of prices with respect to earnings. Journal of Accounting and Economics, 9 (2): 111-138.

Core, J., \& Guay, W. (2002). Estimating the value of employee stock option portfolios and their sensitivities to price and volatility. Journal of Accounting Research 40 (3): 613-630.

Core, J., Guay, W., \& Verrecchia, R. (2003). Price versus non-price performance measures in optimal CEO compensation contracts. The Accounting Review, 78 (4), 957-981.

De Angelis, D. \& Grinstein, Y. (2015). Performance terms in CEO compensation contracts. Review of Finance, 19 (2): 619-651.

Duru, A., \& Reeb, D. (2002). International diversification and analysts' forecast accuracy and bias. The Accounting Review 77: 415-433.

Evans III, J., Gao, Z., Hwang, Y., \& Wu, W. (2017). Performance periods in CEO performance-based equity awards: Theory and evidence. The Accounting Review, forthcoming.

Freeman, R. (1987). The association between accounting earnings and security returns for large and small firms. Journal of Accounting and Economics, 9 (2): 195-228.

Garvey, G. \& Milbourn, T. (2003). Incentive compensation when executives can hedge the market: Evidence of relative performance evaluation in the cross section. The Journal of Finance, LVIII (4), 1557-1582.

Gerakos, J., Ittner, C., \& Larcker, D. (2007). The structure of performance-vested stock option grants. In R. Antle, P. Liang, \& F. Gjesdahl (Eds). 2007. Essays on Accounting Theory in Honour of Joel S. Demski. Norwell, MA: Springer.

Glass Lewis \& Co. (2015). Guidelines for 2015 proxy season, an overview of the Glass Lewis approach to proxy advice. http://www.glasslewis.com/assets/uploads/2013/12/2015_GUIDELINES_United_States.p df.

Gong, G., Li, L., \& Shin, J. 2011. Relative performance evaluation and related peer groups in executive compensation contracts. The Accounting Review, 86 (3), 1007-1043.

Greene, W. (2011), Econometric Analysis. Prentice Hall.

Holmstrom, B. (1979). Moral hazard and observability. Bell Journal of Economics, 10 (1), 74-91.

Holmstrom, B. (1982). Moral hazard in teams. Bell Journal of Economics, 13 (2), 324-340.

Institutional Shareholder Services. (2015). United States summary proxy voting guidelines. 2015 benchmark policy recommendations. https://www.issgovernance.com/file/policy/2015-us-summary-voting-guidelinesupdated.pdf

Ittner, C., Larker, D., \& Rajan, M. (1997). The choice of performance measures in annual bonus contracts. The Accounting Review, 72 (2), 231-255. 
Janakiraman, S., Lambert, R, \& Larcker, D. (1992). An empirical investigation of the relative performance evaluation hypothesis. Journal of Accounting Research, 30 (1), 53-69.

Kuang, Y., \& Qin, B. (2009). Performance-vested stock options and interest alignment. British Accounting Review 41: 46-61.

Kole, S. (1997). The complexity of compensation contracts. Journal of Financial Economics, 43(1): 79-104.

Lambert, R., \& Larcker, D. (1987). An analysis of the use of accounting and market measures of performance in executive compensation contracts. Journal of Accounting Research, 25 (Supplement), 85-125.

Lazear, E. 1995. Personnel Economics. MIT Press: Cambridge, Massachusetts.

Matějka, M., Merchant, K., \& Stede, W. (2009). Employment horizon and the choice of performance measures: Empirical evidence from annual bonus plans of loss-making entities. Journal Management Science, 55 (6), 890-905.

Mittal, V., W. Kamakura, \& R. Govind. (2004). Geographic patterns in customer service and satisfaction: An empirical investigation. Journal of Marketing 68: 48-62.

Murphy, K. (1999). Executive Compensation. Handbook of Labor Economics (Vol. 3; edited by O. Ashenfleter \& D. Card). Amsterdam: North-Holland.

Murphy, K. and T. Sandino. (2010). Executive pay and "independent” compensation consultants. Journal of Accounting and Economics 49 (3): 247-262.

Smith, C., \& R. Watts. (1992). The investment opportunity set and corporate financing, dividend, and compensation policies. Journal of Financial Economics 32, 263-292. 


\section{APPENDIX A: VoTING GUIDELINES FOR EXECUTIVE COMPENSATION BY GLASS LEWIS}

The 2015 voting guidelines of Glass Lewis specify certain elements that are common to most well-structured long-term incentive plans, including:

- No re-testing or lowering of performance conditions;

- Performance metrics that cannot be easily manipulated by management;

- Two or more performance metrics;

- At least one relative performance metric that compares the company's performance to a relevant peer group or index;

- Performance periods of at least three years;

- Stretching metrics that incentivize executives to strive for outstanding performance while not encouraging excessive risk-taking; and

- Individual limits expressed as a percentage of base salary.

Glass Lewis (2015) also suggests that performance measures should be carefully selected and should relate to the specific business/industry in which the company operates and, especially, the key value drivers of the company’s business. 


\section{APPENDIX B: VARIABLE DEFINITIONS}

\begin{tabular}{|c|c|c|}
\hline Variable & Label & Computation \\
\hline AdjROA3 & $\begin{array}{l}\text { Industry-adjusted } \\
\text { ROA }\end{array}$ & $\begin{array}{l}=\text { A firm's ROA minus 2-digit SIC industry's average ROA; then } \\
\text { averaged over prior three years }\end{array}$ \\
\hline BHAR3 & Abnormal returns & $\begin{aligned} &= \text { Market-adjusted buy-and-hold abnormal returns, cumulated over } \\
& \text { prior three years }\end{aligned}$ \\
\hline$B M$ & Book-to-market ratio & $\begin{array}{l}=\text { Book equity/market capitalization, where book equity is common } \\
\text { equity, adjusted for deferred tax liabilities, and market } \\
\text { capitalization is from four months after fiscal year end }\end{array}$ \\
\hline $\begin{array}{l}\text { BrdIndp } \\
\text { CEOAge }\end{array}$ & $\begin{array}{l}\text { Board independence } \\
\text { CEO's age }\end{array}$ & $=$ Number of independent directors / total number of directors \\
\hline CEONeW & New CEO & $\begin{array}{l}=1 \text { if a new CEO is appointed in the current fiscal year, and } 0 \\
\text { otherwise }\end{array}$ \\
\hline CEOWlth & CEO wealth & $\begin{array}{l}=\text { The natural logarithm of the value of equity (including both } \\
\text { stocks and stock options) held by CEO }\end{array}$ \\
\hline ComShk & Common shock & $\begin{aligned}= & \mathrm{R}^{2} \text { of the regression of a firm's stock returns on value-weighted } \\
& \text { 2-digit SIC industry index returns over } 36 \text { months }\end{aligned}$ \\
\hline Dual & Dual role of CEO & $\begin{array}{l}=1 \text { if } \mathrm{CEO} \text { also holds the role of chairman of the board, and } 0 \\
\text { otherwise }\end{array}$ \\
\hline ExCash & $\begin{array}{l}\text { CEO's excess cash } \\
\text { compensation }\end{array}$ & $\begin{aligned}= & \text { CEO's annual cash compensation (=salary+bonus) - average } \\
& \text { CEO cash compensation in industry peers (defined by two-digit } \\
& \text { SIC, size decile, and year) }\end{aligned}$ \\
\hline LongPeriod & $\begin{array}{l}\text { Long performance } \\
\text { period }\end{array}$ & $=1$ if the performance period is at least three years and 0 otherwise \\
\hline$I H$ & $\begin{array}{l}\text { Institutional } \\
\text { ownership }\end{array}$ & $\begin{array}{l}=\text { Number of shares held by institutional investors/total number of } \\
\text { shares outstanding }\end{array}$ \\
\hline IndConcen & $\begin{array}{l}\text { Industry } \\
\text { Concentration }\end{array}$ & $\begin{array}{l}=\text { The sum of the squares of the market shares of the firms' sales } \\
\text { within each two-digit SIC industry }\end{array}$ \\
\hline Invst3 & Investment intensity & $\begin{aligned}= & (\mathrm{R} \& \mathrm{D}+\text { advertising }+ \text { capital expenditures }) / \text { average total assets, } \\
& \text { averaged over prior three years }\end{aligned}$ \\
\hline Market & $\begin{array}{l}\text { Use of market } \\
\text { metrics }\end{array}$ & $\begin{aligned}= & 1 \text { if stock returns or prices are used as performance metrics in } \mathrm{p}-\mathrm{v} \\
& \text { equity awards }\end{aligned}$ \\
\hline MultMetrics & $\begin{array}{l}\text { Use of multiple } \\
\text { metrics }\end{array}$ & $=1$ if more than one metric is used, and 0 otherwise \\
\hline$P V$ & $\begin{array}{l}\text { Granting p-v equity } \\
\text { awards }\end{array}$ & $\begin{array}{l}=1 \text { if a firm grants p-v equity awards (in forms of restricted stocks, } \\
\text { restricted stock units, stock options or SARs) to its executives, } \\
\text { and } 0 \text { otherwise. }\end{array}$ \\
\hline |Ret_RkAdj| & $\begin{array}{l}\text { Absolute value of } \\
\text { size-adjusted returns }\end{array}$ & $\begin{array}{l}=\text { the absolute difference between a firm's annual stock returns and } \\
\text { the median annual stock returns for the firm's corresponding size } \\
\text { decile }\end{array}$ \\
\hline$R P E$ & $\begin{array}{l}\text { Relative } \\
\text { performance } \\
\text { evaluation }\end{array}$ & $\begin{array}{l}=1 \text { if any performance metric in a firm's CEO p-v equity } \\
\text { compensation is benchmarked against its peers or an index, and } 0 \\
\text { otherwise }\end{array}$ \\
\hline RtVar & $\begin{array}{l}\text { Relative volatility of } \\
\text { returns to earnings }\end{array}$ & $\begin{aligned}= & \text { Standard deviation of daily returns over the past year, defined by } \\
& \text { standard deviation of ROA over the past } 12 \text { quarters }\end{aligned}$ \\
\hline Segmt & & Number of business segments \\
\hline Size & Size & $=$ Natural log of market capitalization \\
\hline Volt & Return volatility & $\begin{aligned}= & \text { Standard deviation of daily stock returns over previous } 12 \\
& \text { months (minimum } 180 \text { trading days) }\end{aligned}$ \\
\hline
\end{tabular}




\section{Figure I. Performance-vested Equity Awards and Other Components of CEO Compensation}

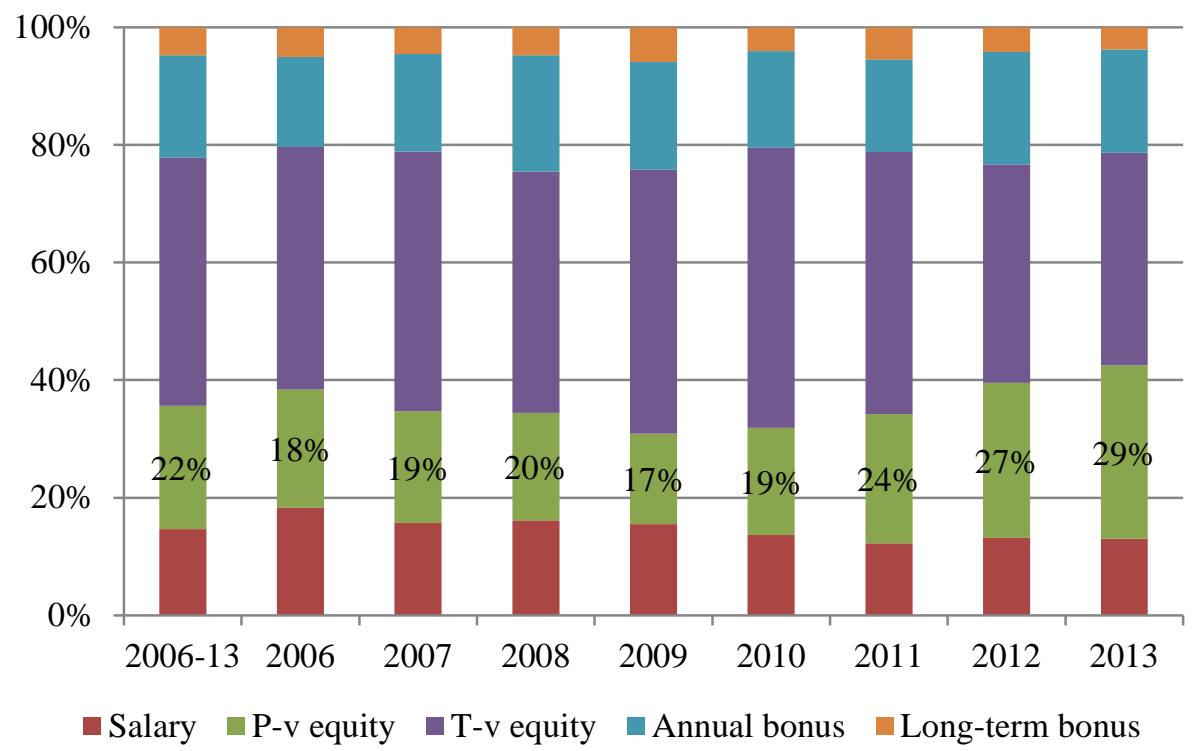

Panel A. Components of CEO compensation, as percentages of total compensation value $100 \%$

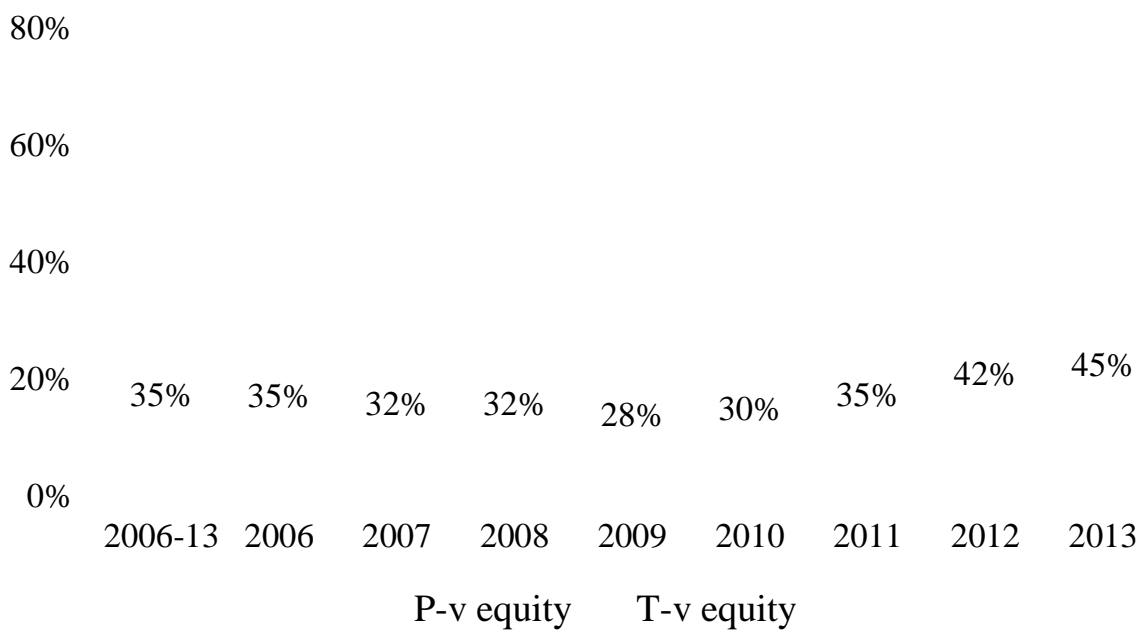

Panel B. Performance- and time-vested components, as percentages of total equity compensation value

This figure shows performance-vested equity awards and other components of CEO compensation as percentages of total compensation value (Panel A) and total equity compensation value (Panel B). The sample is S\&P 500 industrial firms (financials and utilities excluded) between 2006 and 2013. 
Table 1. Construction of the Sample and Changes of Sample Size

Sample selection process

Number of firm-year

S\&P 500 firms between fiscal years 2006-2013

4,000

- No proxy statements due to delisting, M\&A, etc.

- Financial institutions and utilities

- No equity grants to CEOs

- Only t-v equity grants to CEOs

Firms granting p-v equity awards to CEOs

- Missing accounting, price, corporate governance data

Final sample 
Table 2. Key Contractual Features of CEO Performance-vested Equity Compensation

Panel A. Types of performance metrics

\begin{tabular}{ccccccccc}
\hline & & \multicolumn{9}{c}{ Accounting } & & & Other & Non- \\
\cline { 3 - 6 } & & $\mathrm{N}$ & Esset & & & & & \\
Earnings & utilization & Sales & Cash & Market & financial & financial \\
\hline 2006-08 & 435 & 240 & 151 & 98 & 41 & 132 & 29 & 26 \\
& & $(55.2 \%)$ & $(34.7 \%)$ & $(22.5 \%)$ & $(9.4 \%)$ & $(30.3 \%)$ & $(6.7 \%)$ & $(6.0 \%)$ \\
$2009-13$ & 1,007 & 510 & 263 & 237 & 110 & 417 & 63 & 50 \\
& & $(50.6 \%)$ & $(26.1 \%)$ & $(23.5 \%)$ & $(10.9 \%)$ & $(41.4 \%)$ & $(6.3 \%)$ & $(5.0 \%)$ \\
\hline $2006-13$ & 1,442 & 750 & 414 & 335 & 151 & 549 & 92 & 76 \\
& & $(52.0 \%)$ & $(28.7 \%)$ & $(23.2 \%)$ & $(10.5 \%)$ & $(38.1 \%)$ & $(6.4 \%)$ & $(5.3 \%)$ \\
\hline
\end{tabular}

Panel B. Use of RPE and length of performance period

\begin{tabular}{|c|c|c|c|c|c|c|c|c|}
\hline & \multirow[b]{2}{*}{$\mathrm{N}$} & \multicolumn{2}{|c|}{ Use of RPE } & \multicolumn{5}{|c|}{ Length of performance period(years) } \\
\hline & & Yes & No & $\leq 1$ & 2 & 3 & 4 & $\geq 5$ \\
\hline 2006-08 & 435 & $\begin{array}{c}162 \\
(37.2 \%)\end{array}$ & $\begin{array}{c}273 \\
(62.8 \%)\end{array}$ & $\begin{array}{c}82 \\
(18.9 \%)\end{array}$ & $\begin{array}{c}27 \\
(6.2 \%)\end{array}$ & $\begin{array}{c}287 \\
(66.0 \%)\end{array}$ & $\begin{array}{c}19 \\
(4.4 \%)\end{array}$ & $\begin{array}{c}20 \\
(4.6 \%)\end{array}$ \\
\hline 2009-13 & 1,007 & $\begin{array}{c}422 \\
(41.9 \%)\end{array}$ & $\begin{array}{c}585 \\
(58.1 \%)\end{array}$ & $\begin{array}{c}210 \\
(20.9 \%)\end{array}$ & $\begin{array}{c}37 \\
(3.7 \%)\end{array}$ & $\begin{array}{c}701 \\
(69.6 \%)\end{array}$ & $\begin{array}{c}26 \\
(2.6 \%)\end{array}$ & $\begin{array}{c}33 \\
\text { ( } 3.3 \%)\end{array}$ \\
\hline 2006-13 & 1,442 & $\begin{array}{c}584 \\
(40.5 \%)\end{array}$ & $\begin{array}{c}858 \\
(59.5 \%) \\
\end{array}$ & $\begin{array}{c}292 \\
(20.2 \%)\end{array}$ & $\begin{array}{c}64 \\
(4.4 \%)\end{array}$ & $\begin{array}{c}988 \\
(68.5 \%)\end{array}$ & $\begin{array}{c}45 \\
(3.1 \%)\end{array}$ & $\begin{array}{c}53 \\
(3.7 \%)\end{array}$ \\
\hline
\end{tabular}

Panel C. Number of metrics

\begin{tabular}{lcccccc}
\hline & & \multicolumn{5}{c}{ Number of metrics } \\
\cline { 3 - 7 } & $\mathrm{N}$ & 1 & 2 & 3 & 4 & $\geq 5$ \\
\hline $2006-08$ & 435 & 213 & 173 & 38 & 11 & 0 \\
& & $(49.0 \%)$ & $(39.8 \%)$ & $(8.7 \%)$ & $(2.5 \%)$ & $(0.0 \%)$ \\
$2009-13$ & 1,007 & 536 & 328 & 115 & 27 & 1 \\
& & $(53.2 \%)$ & $(32.6 \%)$ & $(11.4 \%)$ & $(2.7 \%)$ & $(0.1 \%)$ \\
\hline $2006-13$ & 1,442 & 749 & 501 & 153 & 38 & 1 \\
& & $(51.9 \%)$ & $(34.7 \%)$ & $(10.6 \%)$ & $(2.6 \%)$ & $(0.1 \%)$ \\
\hline
\end{tabular}

This table shows the key contractual features of CEO p-v equity compensation. When a CEO receives more than one p-v equity award, only the features of the award with the largest fair value are considered. Panel A shows the types of performance metrics specified in p-v equity awards. The "Earnings" category includes all metrics directly derived from earnings. The "Asset utilization" category includes return on equity, return on assets, return on invested capital, EVA, working capital, etc. The "Sales" category includes all metrics directly related to sales/revenue. The "Cash" category includes operating cash flow, free cash flow, and other cash measures. The "Market" category includes stock prices or stock returns. The "Other financial" category includes financial measures other than the above measures. The "Non-financial" category includes all non-financial metrics, such as customer satisfaction, safety, innovation, etc. Panel B shows the use of relative performance evaluation (RPE) and the length of the performance period. A firm is considered as using RPE if it benchmarks any performance metric against peers (including an index). The performance period is a period over which performance is measured for the purpose of determining the payout of CEOs' p-v equity awards. Panel C reports numbers of metrics. Numbers in parentheses are row percentages. 
Table 3. Relation between the Use of RPE and Performance Metrics

Panel A. Frequency counts by RPE and type of performance metrics

\begin{tabular}{lccc}
\hline \multirow{2}{*}{ Use of market } & \multicolumn{2}{c}{ Use of RPE } & \\
\cline { 2 - 3 } metrics & Yes & No & Total \\
\hline Yes & 482 & 67 & 549 \\
& $(87.8 \%)$ & $(12.2 \%)$ & \\
No & 102 & 791 & 893 \\
& $(11.4 \%)$ & $(88.6 \%)$ & \\
\hline Total & 584 & 858 & 1,442 \\
& $(40.5 \%)$ & $(59.5 \%)$ & \\
\hline
\end{tabular}

Panel B. Summary statistics of key variables

\begin{tabular}{lrrrrrrrc}
\hline $\begin{array}{l}\text { Variable } \\
(\mathrm{N}=1,442)\end{array}$ & Mean & STDev & \multicolumn{1}{c}{ Min } & Q1 & Median & Q3 & Max & $\begin{array}{c}\text { Corr. with } \\
\text { RPE }\end{array}$ \\
\hline RPE & 0.405 & 0.491 & 0.000 & 0.000 & 0.000 & 1.000 & 1.000 & \\
Market & 0.381 & 0.486 & 0.000 & 0.000 & 0.000 & 1.000 & 1.000 & $0.755^{* * *}$ \\
ComShk & 0.465 & 0.223 & 0.000 & 0.297 & 0.478 & 0.631 & 0.997 & $0.142^{* * *}$ \\
IndConcen & 0.090 & 0.084 & 0.026 & 0.039 & 0.050 & 0.109 & 0.456 & $-0.079 * * *$ \\
CEOWlth & 10.189 & 1.349 & 3.112 & 9.400 & 10.212 & 10.956 & 14.309 & 0.041 \\
CEOAge & 55.950 & 5.772 & 39.000 & 52.000 & 56.000 & 60.000 & 75.000 & $0.114^{* * *}$ \\
$\mid$ Ret_RkAdj| & 0.091 & 0.109 & 0.000 & 0.021 & 0.058 & 0.118 & 0.893 & -0.030 \\
AdjROA3 & 0.002 & 0.051 & -0.189 & -0.026 & 0.002 & 0.029 & 0.143 & -0.037 \\
\hline
\end{tabular}


Panel C. Use of market metrics and RPE: Logit regression

\begin{tabular}{|c|c|c|c|c|c|c|c|}
\hline & \multirow{3}{*}{$\begin{array}{l}\text { Pred. } \\
\text { sign }\end{array}$} & \multicolumn{6}{|c|}{ Dependent variable: $R P E$} \\
\hline & & \multicolumn{2}{|c|}{ (1.i) } & \multicolumn{2}{|c|}{ (1.ii) } & \multicolumn{2}{|c|}{ (1.iii) } \\
\hline & & Coef. & M.E. & Coef. & M.E. & Coef. & M.E \\
\hline \multirow[t]{2}{*}{ Market } & + & & & $4.122 * * *$ & $0.774 * * *$ & $4.237 * * *$ & $0.785^{* * *}$ \\
\hline & & & & $(15.24)$ & $(28.66)$ & $(14.90)$ & $(28.86)$ \\
\hline \multirow[t]{2}{*}{ ComShk } & + & $1.302^{* * *}$ & $0.312 * * *$ & 0.595 & 0.139 & 0.551 & 0.127 \\
\hline & & $(2.39)$ & $(2.40)$ & $(0.78)$ & $(0.78)$ & $(0.72)$ & $(0.71)$ \\
\hline \multirow[t]{2}{*}{ IndConcen } & - & $-2.532 *$ & $-0.607^{*}$ & 0.403 & 0.094 & 0.416 & 0.096 \\
\hline & & $(-1.54)$ & $(-1.55)$ & $(0.17)$ & $(0.17)$ & $(0.18)$ & $(0.18)$ \\
\hline \multirow[t]{2}{*}{ CEOWlth } & - & 0.002 & 0.000 & 0.138 & 0.032 & 0.157 & 0.036 \\
\hline & & $(0.02)$ & $(0.02)$ & $(1.03)$ & $(1.03)$ & $(1.27)$ & $(1.27)$ \\
\hline \multirow[t]{2}{*}{ CEOAge } & - & $0.030 * *$ & $0.007 * *$ & 0.027 & 0.006 & 0.011 & 0.002 \\
\hline & & $(1.80)$ & $(1.81)$ & $(1.16)$ & $(1.17)$ & $(0.44)$ & $(0.45)$ \\
\hline \multirow[t]{2}{*}{ |Ret_RkAdj| } & - & -0.461 & -0.111 & -0.332 & -0.077 & -0.345 & -0.080 \\
\hline & & $(-0.76)$ & $(-0.76)$ & $(-0.38)$ & $(-0.38)$ & $(-0.40)$ & $(-0.40)$ \\
\hline \multirow[t]{2}{*}{ AdjROA3 } & $+/-$ & -1.407 & -0.337 & 1.398 & 0.326 & 2.244 & 0.518 \\
\hline & & $(-0.75)$ & $(-0.75)$ & $(0.52)$ & $(0.52)$ & $(0.80)$ & (0.79) \\
\hline \multirow[t]{2}{*}{$B M$} & & $0.582^{* *}$ & 0.139** & 0.343 & 0.080 & 0.519 & 0.120 \\
\hline & & $(1.70)$ & $(1.70)$ & $(0.84)$ & $(0.84)$ & (1.25) & (1.24) \\
\hline \multirow[t]{2}{*}{ Size } & & 0.107 & 0.026 & -0.092 & -0.021 & $-0.226^{*}$ & $-0.052^{*}$ \\
\hline & & $(0.94)$ & $(0.94)$ & $(-0.64)$ & $(-0.64)$ & $(-1.36)$ & $(-1.36)$ \\
\hline \multirow[t]{2}{*}{$I H$} & & & & & & -1.323 & -0.306 \\
\hline & & & & & & $(-1.25)$ & $(-1.25)$ \\
\hline \multirow[t]{2}{*}{ BrdIndp } & & & & & & $4.574^{* * *}$ & $1.056^{* * *}$ \\
\hline & & & & & & $(3.94)$ & (3.78) \\
\hline \multirow[t]{2}{*}{ Dual } & & & & & & $0.564 * *$ & $0.127 * *$ \\
\hline & & & & & & $(1.95)$ & $(2.04)$ \\
\hline \multirow[t]{2}{*}{ CEONew } & & & & & & -0.145 & -0.033 \\
\hline & & & & & & $(-0.48)$ & $(-0.49)$ \\
\hline & Yes & & Yes & & Yes & \\
\hline \multicolumn{2}{|c|}{$\begin{array}{l}\text { Year fixed effeCt } \\
\text { Intercept }\end{array}$} & Yes & & Yes & & Yes & \\
\hline \multicolumn{2}{|l|}{ Pseudo R ${ }^{2}$} & 0.047 & & 0.478 & & 0.501 & \\
\hline \multicolumn{2}{|l|}{$\mathrm{N}$} & 1,442 & & 1,442 & & 1,442 & \\
\hline
\end{tabular}

This table reports the use of RPE in CEO p-v equity compensation. Panel A shows frequency counts by the use of RPE and metric types. Panel B shows summary statistics and Pearson correlations of the key variables for Hypothesis 1. Panel C shows logit regression of RPE on Market and other determinants. RPE equals one if any performance metric is benchmarked against peers (including an index), and zero otherwise. Market equals one if a firm uses either stock returns or prices as performance metrics, and zero otherwise. ComShk is common shocks to a firm's performance, measured as the $\mathrm{R}^{2}$ from regressing firm-specific stock returns on value-weighted industry returns over prior 36 months. IndConcen is industry concentration, calculated as the sum of squared market shares of individual firms' sales within each two-digit SIC industry. CEOWlth is the CEO's wealth, calculated as the natural logarithm of the value of a CEO's equity holding (both stocks and stock options). CEOAge is the age of CEO. $\mid$ Ret_RkAdj| is the absolute difference between a firm's annual stock returns and the median annual stock returns for the firm's corresponding decile. AdjROA3 is industry-adjusted return on assets, averaged over prior three years. $B M$ is the book-to-market ratio. Size is the natural logarithm of market capitalization. $I H$ is institutional holdings, which equals the number of shares held by institutional investors, scaled by the total number of shares outstanding. BrdIndp is board independence, calculated as the number of independent directors, scaled by the total number of directors. Dual equals one if the CEO is also the chairperson 
of the board, and zero otherwise. CEONew indicates a new CEO. See Appendix B for more details. Z-statistics (in parentheses) are based on standard errors which are clustered by firms. ***, **, * indicate being significant at levels of $1 \%, 5 \%$, and $10 \%$, respectively, in one-sided tests. 
Table 4. Relations between Performance Period and Metric Numbers and Performance Metrics

Panel A. Frequency counts by performance period, metric numbers, and metric types

\begin{tabular}{lcccccc} 
Use of market & \multicolumn{2}{c}{ Performance period } & & \multicolumn{2}{c}{ Number of metrics } & \\
\cline { 2 - 3 } metrics & $1 \sim 2$ years & $\geq 3$ years & & 1 metric & $\geq 2$ metrics & Total \\
\hline Yes & 22 & 527 & & 300 & 249 & 549 \\
& $(4.0 \%)$ & $(96.0 \%)$ & & $(54.6 \%)$ & $(45.4 \%)$ & \\
No & 334 & 559 & & 449 & 444 & 893 \\
& $(37.4 \%)$ & $(62.6 \%)$ & & $(50.3 \%)$ & $(49.7 \%)$ & \\
\hline Total & 356 & 1,086 & & 749 & 693 & 1,442 \\
& $(24.7 \%)$ & $(75.3 \%)$ & $(51.9 \%)$ & $(48.1 \%)$ & \\
\hline
\end{tabular}

Panel B. Summary statistics of key variables

\begin{tabular}{lccccccccc}
\hline Variable & & & & & & & & \multicolumn{2}{c}{ Corr. with } \\
\cline { 7 - 10 }$(\mathrm{N}=1,442)$ & Mean & STDev & Min & Q1 & Median & Q3 & Max & LongPeriod & MultMetrics \\
\hline LongPeriod & 0.753 & 0.431 & 0.000 & 1.000 & 1.000 & 1.000 & 1.000 & & \\
MultMetrics & 0.481 & 0.500 & 0.000 & 0.000 & 0.000 & 1.000 & 1.000 & & \\
Market & 0.381 & 0.486 & 0.000 & 0.000 & 0.000 & 1.000 & 1.000 & $0.376^{* * *}$ & -0.042 \\
AdjROA3 & 0.002 & 0.051 & -0.189 & -0.026 & 0.002 & 0.029 & 0.143 & 0.031 & \\
ExCash & 0.019 & 0.517 & -0.784 & -0.265 & -0.058 & 0.147 & 4.966 & -0.016 & \\
Volt & 1.219 & 0.133 & 0.619 & 1.149 & 1.219 & 1.295 & 1.748 & -0.021 & -0.026 \\
Invst3 & 0.090 & 0.057 & 0.007 & 0.049 & 0.080 & 0.115 & 0.351 & 0.036 & 0.011 \\
Segmt & 3.644 & 2.173 & 1.000 & 2.000 & 3.500 & 5.000 & 14.000 & $0.060^{* *}$ & $0.052^{* *}$ \\
\hline
\end{tabular}


Panel C. Use of market metrics and performance period: Logit regression

\begin{tabular}{|c|c|c|c|c|c|c|c|}
\hline & \multirow{3}{*}{$\begin{array}{l}\text { Pred. } \\
\text { sign }\end{array}$} & \multicolumn{6}{|c|}{ Dependent variable: LongPeriod } \\
\hline & & \multicolumn{2}{|c|}{$(2 . \mathrm{i})$} & \multicolumn{2}{|c|}{ (2.ii) } & \multicolumn{2}{|c|}{ (2.iii) } \\
\hline & & Coef. & M.E. & Coef. & M.E. & Coef. & M.E \\
\hline \multirow[t]{2}{*}{ Market } & + & & & $2.654^{* * *}$ & $0.328^{* * *}$ & $2.647^{* * *}$ & $0.314^{* * *}$ \\
\hline & & & & $(8.97)$ & $(10.13)$ & $(8.74)$ & $(9.99)$ \\
\hline \multirow[t]{2}{*}{ AdjROA3 } & + & 1.327 & 0.241 & 2.606 & 0.375 & $3.431^{*}$ & $0.473^{*}$ \\
\hline & & $(0.56)$ & $(0.56)$ & $(1.07)$ & $(1.07)$ & $(1.47)$ & $(1.45)$ \\
\hline \multirow[t]{2}{*}{ ExCash } & - & $-0.319 *$ & $-0.058 *$ & -0.211 & -0.030 & -0.122 & -0.017 \\
\hline & & $(-1.53)$ & $(-1.54)$ & $(-0.96)$ & $(-0.97)$ & $(-0.60)$ & $(-0.60)$ \\
\hline \multirow[t]{2}{*}{ Volt } & + & 0.025 & 0.005 & -0.074 & -0.011 & -0.353 & -0.049 \\
\hline & & $(0.04)$ & $(0.04)$ & $(-0.11)$ & $(-0.11)$ & $(-0.51)$ & $(-0.51)$ \\
\hline \multirow[t]{2}{*}{ Invst3 } & + & $2.652 *$ & $0.482 *$ & 1.042 & 0.150 & 2.329 & 0.321 \\
\hline & & $(1.32)$ & $(1.32)$ & $(0.46)$ & $(0.46)$ & $(0.98)$ & $(0.97)$ \\
\hline \multirow[t]{2}{*}{ Segmt } & + & $0.081^{*}$ & $0.015^{*}$ & 0.027 & 0.004 & 0.017 & 0.002 \\
\hline & & $(1.51)$ & $(1.52)$ & $(0.47)$ & $(0.47)$ & $(0.30)$ & $(0.30)$ \\
\hline \multirow[t]{2}{*}{$B M$} & & $0.484 *$ & $0.088^{*}$ & 0.203 & 0.029 & 0.365 & 0.050 \\
\hline & & $(1.46)$ & $(1.44)$ & $(0.61)$ & $(0.61)$ & (1.04) & (1.03) \\
\hline \multirow[t]{2}{*}{ Size } & & $0.258 * * *$ & $0.047 * * *$ & $0.200 *$ & $0.029 * *$ & 0.019 & 0.003 \\
\hline & & $(2.35)$ & $(2.37)$ & (1.63) & (1.65) & $(0.14)$ & $(0.14)$ \\
\hline \multirow[t]{2}{*}{$I H$} & & & & & & $-2.644 * * *$ & $-0.364 * * *$ \\
\hline & & & & & & $(-2.52)$ & $(-2.52)$ \\
\hline \multirow[t]{2}{*}{ BrdIndp } & & & & & & $2.828 * * *$ & $0.390 * * *$ \\
\hline & & & & & & $(2.66)$ & $(2.55)$ \\
\hline \multirow[t]{2}{*}{ Dual } & & & & & & $0.559 * *$ & $0.081^{* *}$ \\
\hline & & & & & & $(2.25)$ & $(2.17)$ \\
\hline \multirow[t]{2}{*}{ CEONew } & & & & & & 0.301 & $0.038 *$ \\
\hline & & & & & & $(1.23)$ & $(1.34)$ \\
\hline \multirow{2}{*}{\multicolumn{2}{|c|}{$\begin{array}{l}\text { Year fixed effect } \\
\text { Intercept }\end{array}$}} & Yes & & Yes & & Yes & \\
\hline & & Yes & & Yes & & Yes & \\
\hline \multicolumn{2}{|l|}{ Pseudo $\mathrm{R}^{2}$} & 0.026 & & 0.166 & & 0.199 & \\
\hline \multicolumn{2}{|l|}{$\mathrm{N}$} & 1,442 & & 1,442 & & 1,442 & \\
\hline
\end{tabular}


Panel D. Use of market metrics and metric numbers: Logit regression

\begin{tabular}{|c|c|c|c|c|c|c|c|}
\hline & \multirow{3}{*}{$\begin{array}{c}\text { Pred. } \\
\text { sign }\end{array}$} & \multicolumn{6}{|c|}{ Dependent variable: MultMetrics } \\
\hline & & \multicolumn{2}{|c|}{ (3.i) } & \multicolumn{2}{|c|}{ (3.ii) } & \multicolumn{2}{|c|}{ (3.iii) } \\
\hline & & Coef. & M.E. & Coef. & M.E. & Coef. & M.E \\
\hline \multirow[t]{2}{*}{ Market } & - & & & -0.214 & -0.053 & -0.229 & -0.057 \\
\hline & & & & $(-0.97)$ & $(-0.97)$ & $(-1.05)$ & $(-1.05)$ \\
\hline \multirow[t]{2}{*}{ Volt } & + & 0.355 & 0.088 & 0.356 & 0.089 & 0.420 & 0.105 \\
\hline & & $(0.62)$ & $(0.62)$ & $(0.62)$ & $(0.62)$ & $(0.73)$ & $(0.73)$ \\
\hline \multirow[t]{2}{*}{ Invst3 } & + & -0.027 & -0.007 & 0.195 & 0.049 & 0.766 & 0.191 \\
\hline & & $(-0.01)$ & $(-0.01)$ & $(0.11)$ & $(0.11)$ & $(0.41)$ & $(0.41)$ \\
\hline \multirow[t]{2}{*}{ Segmt } & + & 0.051 & 0.013 & 0.057 & 0.014 & 0.059 & 0.015 \\
\hline & & $(1.09)$ & (1.09) & $(1.19)$ & $(1.19)$ & $(1.23)$ & (1.23) \\
\hline \multirow[t]{2}{*}{$B M$} & & $-0.473^{*}$ & $-0.118 *$ & -0.426 & -0.106 & -0.430 & -0.107 \\
\hline & & $(-1.39)$ & $(-1.39)$ & $(-1.25)$ & $(-1.25)$ & $(-1.25)$ & $(-1.25)$ \\
\hline \multirow[t]{2}{*}{ Size } & & 0.017 & 0.004 & 0.026 & 0.007 & -0.028 & -0.007 \\
\hline & & $(0.16)$ & $(0.16)$ & $(0.25)$ & $(0.25)$ & $(-0.25)$ & $(-0.25)$ \\
\hline \multirow[t]{2}{*}{$I H$} & & & & & & -0.427 & -0.107 \\
\hline & & & & & & $(-0.55)$ & $(-0.55)$ \\
\hline \multirow[t]{2}{*}{ BrdIndp } & & & & & & 0.276 & 0.069 \\
\hline & & & & & & $(0.31)$ & $(0.31)$ \\
\hline \multirow[t]{2}{*}{ Dual } & & & & & & $0.362 * *$ & $0.090 * *$ \\
\hline & & & & & & $(1.78)$ & $(1.80)$ \\
\hline \multirow[t]{2}{*}{ CEONew } & & & & & & -0.128 & -0.032 \\
\hline & & & & & & $(-0.71)$ & $(-0.71)$ \\
\hline \multicolumn{2}{|l|}{ Year fixed effect } & Yes & & Yes & & Yes & \\
\hline \multicolumn{2}{|l|}{ Intercept } & Yes & & Yes & & Yes & \\
\hline \multicolumn{2}{|l|}{ Pseudo $\mathrm{R}^{2}$} & 0.011 & & 0.012 & & 0.019 & \\
\hline \multicolumn{2}{|l|}{$\mathrm{N}$} & 1,442 & & 1,442 & & 1,442 & \\
\hline
\end{tabular}

This table reports the relations between use of market metrics and performance period/metric numbers in CEO p$\mathrm{v}$ equity compensation. Panel A shows frequency counts by performance period/metric numbers and metric types. Panel B shows summary statistics and Pearson correlations of the key variables for Hypotheses 2 and 3. Panel C shows logit regression of LongPeriod on Market and other determinants. LongPeriod equals one if the performance period is equal to or more than three years, and zero otherwise. ExCash is CEO's excess cash compensation, calculated as the difference between a CEO's annual cash compensation (=salary+bonus) and average CEO cash compensation in industry peers (defined by two-digit SIC, size decile, and year). The rest variables are defined the same as in the preceding tables; see Appendix B for more details. Panel D shows logit regression of MultMetrics on Market and other determinants. MultMetrics equals one if a firm uses more than one metric, and zero otherwise. Z-statistics (in parentheses) are based on standard errors which are clustered by firms. $* * *, * *, *$ indicate being significant at levels of $1 \%, 5 \%$, and $10 \%$, respectively, in one-sided tests. 
Table 5. The Choice of Performance Metrics and Joint Determination of Performance Metrics and Other Contractual Features

Panel A. Use of market metrics: Logit regression

\begin{tabular}{|c|c|c|c|c|c|}
\hline & \multirow{3}{*}{$\begin{array}{c}\text { Pred. } \\
\text { Sign }\end{array}$} & \multicolumn{4}{|c|}{ Dependent variable: Market } \\
\hline & & \multicolumn{2}{|c|}{ (4.i) } & \multicolumn{2}{|c|}{ (4.ii) } \\
\hline & & Coef. & M.E. & Coef. & M.E. \\
\hline \multirow[t]{2}{*}{ RtVar } & - & $-0.090 * * *$ & $-0.021 * * *$ & $-0.084^{* *}$ & $-0.019 * *$ \\
\hline & & $(-2.33)$ & $(-2.35)$ & $(-2.28)$ & $(-2.30)$ \\
\hline \multirow[t]{2}{*}{ Invst3 } & + & $3.820 * *$ & $0.886^{* *}$ & $4.042^{* *}$ & $0.937 * *$ \\
\hline & & $(2.04)$ & $(2.03)$ & $(2.13)$ & $(2.13)$ \\
\hline \multirow[t]{2}{*}{ Segmt } & + & $0.108 * *$ & $0.025 * *$ & $0.108 * *$ & $0.025 * *$ \\
\hline & & $(2.08)$ & $(2.08)$ & $(2.09)$ & $(2.08)$ \\
\hline \multirow[t]{2}{*}{ AdjROA3 } & + & 0.691 & 0.160 & & \\
\hline & & $(0.34)$ & $(0.34)$ & & \\
\hline \multirow[t]{2}{*}{ BHAR3 } & $?$ & & & $0.205^{* *}$ & $0.048 * *$ \\
\hline & & & & $(1.72)$ & $(1.72)$ \\
\hline \multirow[t]{2}{*}{$B M$} & & $0.890 * * *$ & $0.207 * * *$ & $0.988 * * *$ & $0.229 * * *$ \\
\hline & & $(2.38)$ & $(2.38)$ & $(2.57)$ & $(2.57)$ \\
\hline \multirow[t]{2}{*}{ Size } & & $0.165^{*}$ & $0.038 *$ & 0.156 & 0.036 \\
\hline & & $(1.34)$ & $(1.34)$ & $(1.26)$ & $(1.26)$ \\
\hline \multirow[t]{2}{*}{$I H$} & & $-1.125^{*}$ & $-0.261 *$ & $-1.269 *$ & $-0.294^{*}$ \\
\hline & & $(-1.37)$ & $(-1.36)$ & $(-1.52)$ & $(-1.52)$ \\
\hline \multirow[t]{2}{*}{ BrdIndp } & & $3.061^{* * *}$ & $0.710^{* * *}$ & $3.117 * * *$ & $0.723 * * *$ \\
\hline & & (3.09) & (3.10) & (3.15) & (3.15) \\
\hline \multirow[t]{2}{*}{ Dual } & & -0.063 & -0.015 & -0.062 & -0.014 \\
\hline & & $(-0.29)$ & $(-0.29)$ & $(-0.29)$ & $(-0.29)$ \\
\hline \multirow[t]{2}{*}{ CEONew } & & 0.093 & 0.022 & 0.119 & 0.028 \\
\hline & & $(0.49)$ & $(0.48)$ & $(0.62)$ & $(0.61)$ \\
\hline Year fixed effect & & Yes & & Yes & \\
\hline Intercept & & Yes & & Yes & \\
\hline Pseudo $\mathrm{R}^{2}$ & & 0.089 & & 0.091 & \\
\hline $\mathrm{N}$ & & 1,442 & & 1,442 & \\
\hline
\end{tabular}


Panel B. Joint determination of metric types and each of the three features-RPE, performance period length, number of metrics: Bivariate Probit Regression (SUR)

\begin{tabular}{|c|c|c|c|c|c|c|c|c|c|}
\hline \multirow[b]{2}{*}{ First equation } & \multirow{2}{*}{$\begin{array}{l}\text { Pred. } \\
\text { sign }\end{array}$} & \multicolumn{2}{|c|}{ Dependent: RPE (1.i) } & \multirow{2}{*}{$\begin{array}{c}\text { Pred. } \\
\text { sign }\end{array}$} & \multicolumn{2}{|c|}{ Dependent: LongPeriod (2.i) } & \multirow{2}{*}{$\begin{array}{c}\text { Pred. } \\
\text { sign }\end{array}$} & \multicolumn{2}{|c|}{ Dependent: MultMetrics (3.i) } \\
\hline & & Coef. & M.E. & & Coef. & M.E. & & Coef. & M.E. \\
\hline \multirow[t]{2}{*}{ Market } & + & $3.175^{* * *}$ & $0.878 * * *$ & + & $2.484 * * *$ & $0.593 * * *$ & - & -0.519 & -0.201 \\
\hline & & $(25.02)$ & $(56.55)$ & & (19.65) & (18.79) & & $(-0.60)$ & $(-0.62)$ \\
\hline \multirow[t]{2}{*}{ ComShk } & + & 0.284 & 0.035 & & & & & & \\
\hline & & $(0.87)$ & $(0.86)$ & & & & & & \\
\hline \multirow[t]{2}{*}{ IndConcen } & + & 0.247 & 0.030 & & & & & & \\
\hline & & $(0.25)$ & $(0.25)$ & & & & & & \\
\hline \multirow[t]{2}{*}{ CEOWlth } & + & $0.071^{*}$ & 0.009 & & & & & & \\
\hline & & (1.29) & $(1.25)$ & & & & & & \\
\hline \multirow[t]{2}{*}{ CEOAge } & + & 0.012 & 0.002 & & & & & & \\
\hline & & $(1.20)$ & $(1.21)$ & & & & & & \\
\hline \multirow[t]{2}{*}{$\left|R e t \_R k A d j\right|$} & - & -0.147 & -0.018 & & & & & & \\
\hline & & $(-0.38)$ & $(-0.38)$ & & & & & & \\
\hline \multirow[t]{2}{*}{ AdjROA3 } & + & 0.978 & 0.120 & + & $1.903 * *$ & $0.479 * *$ & & & \\
\hline & & $(0.83)$ & $(0.81)$ & & $(2.15)$ & $(2.16)$ & & & \\
\hline \multirow[t]{2}{*}{ ExCash } & & & & - & -0.053 & -0.013 & & & \\
\hline & & & & & $(-0.62)$ & $(-0.62)$ & & & \\
\hline \multirow[t]{2}{*}{ Volt } & & & & - & -0.067 & -0.017 & + & 0.182 & 0.070 \\
\hline & & & & & $(-0.25)$ & & & $(0.49)$ & $(0.48)$ \\
\hline \multirow[t]{2}{*}{ Invst3 } & & & & + & -1.036 & -0.261 & + & 0.486 & 0.186 \\
\hline & & & & & $(-0.79)$ & $(-0.79)$ & & $(0.37)$ & $(0.38)$ \\
\hline \multirow[t]{2}{*}{ Segmt } & & & & + & -0.024 & -0.006 & + & 0.044 & $0.017 *$ \\
\hline & & & & & $(-0.82)$ & $(-0.82)$ & & $(1.28)$ & $(1.35)$ \\
\hline Control & & \multicolumn{2}{|c|}{ Same as Table 3} & & \multicolumn{2}{|c|}{ Same as Table 4} & & \multicolumn{2}{|c|}{ Same as Table 4} \\
\hline
\end{tabular}


segments. Invst3 is investment intensity, calculated as the sum of R\&D, advertising, capital expenditures, scaled by average total assets, and is then averaged over past three years. BHAR3 is market-adjusted buy-and-hold abnormal returns, cumulated over prior three years. The rest variables are defined in the preceding tables; see Appendix B for more details. Panel B reports the joint estimation of metric types and each of the three contractual feature (RPE, performance period, number of metrics), using seemingly unrelated probit regressions. Z-statistics (in parentheses) are based on standard errors which are clustered by firms. ***, **, * indicate being significant at levels of $1 \%$, $5 \%$, and $10 \%$, respectively, in one-sided tests. 
Table 6. Interdependence among RPE, Performance Period, and Metric Numbers

\begin{tabular}{|c|c|c|c|c|c|}
\hline & & Performa & riod (yrs.) & Metr & nbers \\
\hline \multicolumn{2}{|c|}{ RPE use } & $1 \sim 2$ & $\geq 3$ & 1 & $\geq 2$ \\
\hline Yes & $\begin{array}{c}584 \\
{[40.5 \%]}\end{array}$ & $\begin{array}{c}30 \\
(5.1 \%)\end{array}$ & $\begin{array}{c}554 \\
(94.9 \%)\end{array}$ & $\begin{array}{c}280 \\
(47.9 \%)\end{array}$ & $\begin{array}{c}304 \\
(52.1 \%)\end{array}$ \\
\hline No & $\begin{array}{c}858 \\
{[59.5 \%]}\end{array}$ & $\begin{array}{c}326 \\
(38.0 \%) \\
\end{array}$ & $\begin{array}{c}532 \\
(62.0 \%)\end{array}$ & $\begin{array}{c}413 \\
(48.1 \%)\end{array}$ & $\begin{array}{c}445 \\
(51.9 \%) \\
\end{array}$ \\
\hline Total & 1,442 & $\begin{array}{c}356 \\
(24.7 \%)\end{array}$ & $\begin{array}{c}1,086 \\
(75.3 \%)\end{array}$ & $\begin{array}{c}693 \\
(48.1 \%)\end{array}$ & $\begin{array}{c}749 \\
(51.9 \%)\end{array}$ \\
\hline
\end{tabular}


Panel B. Interdependence among RPE, performance period, and metric numbers: Seemingly unrelated probit regression

\begin{tabular}{|c|c|c|c|c|c|c|c|c|}
\hline & \multicolumn{2}{|c|}{$\begin{array}{c}\text { (5a) Dependent: } \\
\text { RPE }\end{array}$} & \multicolumn{2}{|c|}{$\begin{array}{c}\text { (5b) Dependent: } \\
\text { LongPeriod }\end{array}$} & \multicolumn{2}{|c|}{$\begin{array}{c}\text { (5c) Dependent: } \\
\text { MultMetrics }\end{array}$} & \multicolumn{2}{|c|}{$\begin{array}{l}\text { (5d) Dependent: } \\
\text { Market }\end{array}$} \\
\hline & Sign & Coef. & Sign & Coef. & Sign & Coef. & Sign & Coef. \\
\hline Market & + & $\begin{array}{l}2.675^{* * *} \\
(15.49)\end{array}$ & + & $\begin{array}{l}1.193^{* * *} \\
(3.37)\end{array}$ & - & $\begin{array}{c}-0.112 \\
(-0.29)\end{array}$ & & \\
\hline$R P E$ & & & + & $\begin{array}{l}0.827 * * * \\
(2.44)\end{array}$ & $?$ & $\begin{array}{r}0.094 \\
(0.29)\end{array}$ & & \\
\hline LongPeriod & & & & & $?$ & $\begin{array}{c}0.142 \\
(0.54)\end{array}$ & & \\
\hline ComShk & + & $\begin{array}{c}0.119 \\
(0.34)\end{array}$ & & & & & & \\
\hline IndConcen & - & $\begin{array}{r}0.252 \\
(0.22)\end{array}$ & & & & & & \\
\hline CEOWlth & - & $\begin{array}{r}0.070 \\
(1.16)\end{array}$ & & & & & & \\
\hline CEOAge & - & $\begin{array}{r}0.012 \\
(1.04)\end{array}$ & & & & & & \\
\hline $\mid$ Ret_RkAdj| & - & $\begin{array}{l}-0.194 \\
(-0.45)\end{array}$ & & & & & & \\
\hline AdjROA3 & & $\begin{array}{r}0.491 \\
(0.37)\end{array}$ & + & $\begin{array}{r}1.472 \\
(1.11)\end{array}$ & & & & \\
\hline ExCash & & & - & $\begin{array}{l}-0.075 \\
(-0.57)\end{array}$ & & & & \\
\hline Volt & & & + & $\begin{array}{r}0.169 \\
(0.48)\end{array}$ & + & $\begin{array}{r}0.040 \\
(0.12)\end{array}$ & & \\
\hline Invst3 & & & + & $\begin{array}{c}0.471 \\
(0.34)\end{array}$ & + & $\begin{array}{l}-0.101 \\
(-0.09)\end{array}$ & + & $\begin{array}{l}2.560 * * \\
(2.23)\end{array}$ \\
\hline Segmt & & & + & $\begin{array}{c}0.005 \\
(0.16)\end{array}$ & + & $\begin{array}{c}0.029 \\
(1.01)\end{array}$ & + & $\begin{array}{l}0.068^{* *} \\
(2.17)\end{array}$ \\
\hline RtVar & & & & & & & - & $\begin{array}{l}-0.046^{* *} \\
(-2.23)\end{array}$ \\
\hline BHAR3 & & & & & & & ? & $\begin{array}{c}0.106^{*} \\
(1.50)\end{array}$ \\
\hline Control variabl & & As in (1.i) & & As in (2.i) & & As in (3.i) & & As in (4.ii) \\
\hline $\begin{array}{l}\text { Intercept } \\
\text { Fixed effect }\end{array}$ & & Yes & & Yes & & Yes & & $\begin{array}{c}\text { Yes } \\
\text { Year } \\
\end{array}$ \\
\hline $\mathrm{N}$ & & 1,442 & & & & & & \\
\hline
\end{tabular}

This table shows the interdependence among RPE, performance period, and metric numbers, while also accounting for the use of market metrics. Panel A reports frequency counts by these three features. Panel B estimates a system of four probit models, whose dependent variables are RPE (in (5a)), LongPeriod (in (5b)), MultMetrics (in (5c)), and Market (in (5d)), respectively. The specification of Model (5a) is identical to that of (1.i) in Table 3; Model (5b) is the same as Model (2.i) in Table 4, except for RPE being an additional independent variable; Model (5c) has RPE and LongPeriod as additional independent variables, but otherwise is same as Model (3.i) in Table 4; and Model (5d) is identical to (4.ii) in Panel A of Table 5. See Appendix B for detailed variable definitions. $* * *, * *$, and $*$ denote significance at less than $1 \%, 5 \%$, and $10 \%$ levels, respectively, in one-sided tests. 
Table 7. Grants of P-V Equity Awards and Their Key Contractual Features

Panel A. Frequency counts of firms granting CEO p-v equity awards vs. firms not granting

\begin{tabular}{|c|c|c|c|}
\hline & \multicolumn{2}{|c|}{ Grant of p-v equity } & \multirow[b]{2}{*}{$\mathrm{N}$} \\
\hline & Yes & No & \\
\hline 2006 & $\begin{array}{c}140 \\
(58.1 \%)\end{array}$ & $\begin{array}{c}101 \\
(41.9 \%)\end{array}$ & 241 \\
\hline 2007 & $\begin{array}{c}162 \\
(57.4 \%)\end{array}$ & $\begin{array}{c}120 \\
(42.6 \%)\end{array}$ & 282 \\
\hline 2008 & $\begin{array}{c}133 \\
(56.6 \%)\end{array}$ & $\begin{array}{c}102 \\
(43.4 \%)\end{array}$ & 235 \\
\hline 2009 & $\begin{array}{c}161 \\
(55.1 \%)\end{array}$ & $\begin{array}{c}131 \\
(44.9 \%)\end{array}$ & 292 \\
\hline 2010 & $\begin{array}{c}189 \\
(62.0 \%)\end{array}$ & $\begin{array}{c}116 \\
(38.0 \%)\end{array}$ & 305 \\
\hline 2011 & $\begin{array}{c}208 \\
(69.8 \%)\end{array}$ & $\begin{array}{c}90 \\
(30.2 \%)\end{array}$ & 298 \\
\hline 2012 & $\begin{array}{c}216 \\
(74.2 \%)\end{array}$ & $\begin{array}{c}75 \\
(25.8 \%)\end{array}$ & 291 \\
\hline 2013 & $\begin{array}{c}233 \\
(78.2 \%) \\
\end{array}$ & $\begin{array}{c}65 \\
(21.8 \%) \\
\end{array}$ & 298 \\
\hline 2006-08 & $\begin{array}{c}435 \\
(57.4 \%)\end{array}$ & $\begin{array}{c}323 \\
(42.6 \%)\end{array}$ & 758 \\
\hline 2009-13 & $\begin{array}{c}1,007 \\
(67.9 \%)\end{array}$ & $\begin{array}{c}477 \\
(32.1 \%)\end{array}$ & 1,484 \\
\hline 2006-13 & $\begin{array}{c}1,442 \\
(64.3 \%) \\
\end{array}$ & $\begin{array}{c}800 \\
(35.7 \%)\end{array}$ & 2,242 \\
\hline
\end{tabular}


Panel B. Granting CEO p-v equity awards: Logit regression

\begin{tabular}{lcc}
\hline \multirow{2}{*}{$\begin{array}{c}\text { Pred. } \\
\text { sign }\end{array}$} & \multicolumn{2}{c}{$(6)$ Dependent: $P V$} \\
\cline { 2 - 4 } BHAR3 & -0.031 & M.E. \\
Volt & $(-0.32)$ & -0.007 \\
& 0.040 & $(-0.32)$ \\
Invst3 & $(0.08)$ & 0.009 \\
& $-3.553^{* * *}$ & $(0.08)$ \\
Segmt & $(-2.59)$ & $-0.806^{* * *}$ \\
& 0.047 & $(-2.59)$ \\
Size & $(1.09)$ & 0.011 \\
& 0.089 & $(1.09)$ \\
IH & $(0.95)$ & 0.020 \\
& -0.597 & $(0.95)$ \\
BrdIndp & $(-0.85)$ & -0.135 \\
& $1.434^{* *}$ & $(-0.86)$ \\
Dual & $(2.09)$ & $0.325^{* * *}$ \\
CEONew & -0.214 & $(2.09)$ \\
& $(-1.24)$ & -0.048 \\
Fixed effect & -0.086 & $(-1.25)$ \\
Pseudo R ${ }^{2}$ & $(-0.57)$ & -0.020 \\
$\mathrm{~N}$ & Year & $(-0.56)$ \\
\hline
\end{tabular}


Panel C. Determination of key contractual features, controlling for grant decision: Heckman section procedure
(1) Dependent:
(2) Dependent:
(3) Dependent:
(4) Dependent:

\begin{tabular}{|c|c|c|c|c|c|c|c|c|}
\hline \multirow{2}{*}{$\begin{array}{l}\text { First } \\
\text { equation }\end{array}$} & \multicolumn{2}{|r|}{$R P E$} & \multicolumn{2}{|c|}{ LongPeriod } & \multicolumn{2}{|c|}{ MultMetrics } & \multicolumn{2}{|c|}{ Market } \\
\hline & Sign & Coef. & Sign & Coef. & Sign & Coef. & Sign & Coef. \\
\hline \multirow[t]{2}{*}{ Market } & + & $1.936 * *$ & + & $1.258^{* * *}$ & - & -0.098 & & \\
\hline & & $(2.07)$ & & $(9.77)$ & & $(-0.96)$ & & \\
\hline \multirow[t]{2}{*}{ ComShk } & + & 0.273 & & & & & & \\
\hline & & $(0.97)$ & & & & & & \\
\hline \multirow[t]{2}{*}{ IndConcen } & - & 0.224 & & & & & & \\
\hline & & $(0.24)$ & & & & & & \\
\hline \multirow[t]{2}{*}{ CEOWlth } & - & 0.057 & & & & & & \\
\hline & & $(0.75)$ & & & & & & \\
\hline \multirow[t]{2}{*}{ CEOAge } & - & 0.009 & & & & & & \\
\hline & & $(0.60)$ & & & & & & \\
\hline \multirow[t]{2}{*}{ |Ret_RkAdj| } & - & -0.192 & & & & & & \\
\hline & & $(-0.56)$ & & & & & & \\
\hline \multirow[t]{2}{*}{$A d j R O A 3$} & & 0.470 & + & 1.394 & & & & \\
\hline & & $(0.43)$ & & $(1.22)$ & & & & \\
\hline \multirow[t]{2}{*}{ ExCash } & & & - & -0.091 & & & & \\
\hline & & & & $(-0.81)$ & & & & \\
\hline \multirow[t]{2}{*}{ Volt } & & & + & -0.036 & + & 0.205 & & \\
\hline & & & & $(-0.10)$ & & $(0.72)$ & & \\
\hline \multirow[t]{2}{*}{ Invst3 } & & & + & $1.571^{*}$ & + & -0.907 & + & $2.979 * * *$ \\
\hline & & & & $(1.50)$ & & $(-0.93)$ & & $(2.74)$ \\
\hline \multirow[t]{2}{*}{ Segmt } & & & + & 0.003 & + & $0.043 *$ & + & $0.051 *$ \\
\hline & & & & $(0.11)$ & & (1.63) & & $(1.43)$ \\
\hline \multirow[t]{2}{*}{ RtVar } & & & & & & & - & $-0.044 * *$ \\
\hline & & & & & & & & $(-2.07)$ \\
\hline \multirow[t]{2}{*}{ BHAR3 } & & & & & & & $?$ & $0.118^{* *}$ \\
\hline & & & & & & & & $(1.71)$ \\
\hline \multicolumn{2}{|c|}{ Control variables } & As in (1.i) & & As in $(2 . i)$ & & As in (3.i) & & As in (4.ii) \\
\hline \multicolumn{2}{|c|}{ Intercept } & Yes & & Yes & & Yes & & Yes \\
\hline \multicolumn{2}{|c|}{ Fixed effect } & Year & & Year & & Year & & Year \\
\hline \multicolumn{2}{|c|}{ Second equation } & As (6) & & As (6) & & As (6) & & As (6) \\
\hline \multicolumn{2}{|c|}{$\mathrm{N}$} & 2,242 & & 2,242 & & 2,242 & & 2,242 \\
\hline
\end{tabular}

This table reports the determination of key contractual features, controlling for grant decision. Panel A shows frequencies of S\&P 500 industrial firms with and without CEO p-v equity awards. Panel B estimates the propensity of granting p-v equity awards to CEO, where the dependent variable $P V$ equals one if a firm does so, and zero otherwise. Panel C re-estimates the individual feature models ((1)-(4) separately) along with the grant model (6) by Heckman selection models with binary dependent variables. See Appendix B for detailed variable definitions. All models include year-fixed effects and cluster standard errors by firms. Z-statistics are shown in parentheses. ${ }^{* * *},{ }^{* *}$, and ${ }^{*}$ denote significance at less than $1 \%, 5 \%$, and $10 \%$ levels, respectively, in one-sided tests. 
Table 8. Contractual Design of CEO P-V Equity Compensation and Future Performance

\begin{tabular}{llllll}
\hline & \multicolumn{5}{c}{ Future industry-adjusted ROA } \\
\cline { 2 - 6 } Consistent design & Year 1 & Year 2 & Year 3 & Year 4 & Year 5 \\
\hline Yes & 0.096 & 0.099 & 0.092 & 0.096 & 0.098 \\
No & 0.079 & 0.077 & 0.076 & 0.081 & 0.085 \\
Difference & $0.017^{* *}$ & $0.022^{* * *}$ & $0.016^{* *}$ & $0.015^{*}$ & 0.013 \\
\hline $\mathrm{N}$ (No vs. Yes) & $(960 / 458)$ & $(942 / 448)$ & $(863 / 392)$ & $(731 / 293)$ & $(582 / 219)$ \\
\hline This table reports future operating performance subsequent to the grant of p-v equity awards. “Consistent design” \\
refers to firms which use market metrics, RPE, and long performance periods simultaneously. The table shows \\
mean industry-adjusted ROA by year. The difference is tested by one-sided $t$-test and ***, **, and * denote \\
significance at less than 1\%, 5\%, and 10\% levels, respectively. The last row shows numbers of observations for \\
the no- and yes-groups.
\end{tabular}

